\author{
UNIVERSIDADE DE SÃO PAULO \\ ESCOLA DE ENFERMAGEM DE RIBEIRÃO PRETO
}

\title{
AVALIAÇÃO DA PRESENÇA DE DEPRESSÃO ENTRE USUÁRIOS DE PLANTÃO NOTURNO EM UNIDADE DE EMERGÊNCIA
}

Igor Pereira dos Santos

Ribeirão Preto

2008 


\title{
IGOR PEREIRA DOS SANTOS
}

\section{AVALIAÇÃO DA PRESENÇA DE DEPRESSÃO ENTRE USUÁRIOS DE PLANTÃO NOTURNO EM UNIDADE DE EMERGÊNCIA}

\begin{abstract}
Dissertação apresentada ao Programa de PósGraduação em Enfermagem Psiquiátrica da Escola de Enfermagem de Ribeirão Preto da Universidade de São Paulo, para a obtenção do título de Mestre em Enfermagem, inserida na linha de pesquisa "Enfermagem Psiquiátrica: o doente, a doença e as práticas terapêuticas".
\end{abstract}

Orientadora: $\operatorname{Prof}^{\mathrm{a}} \mathrm{Dr}^{\mathrm{a}}$ Antônia Regina Ferreira Furegato

Ribeirão Preto

2008 


\section{FOLHA DE APROVAÇÃO}

Igor Pereira dos Santos

Avaliação da presença de depressão entre usuários de plantão noturno em unidade de emergência

Dissertação apresentada à Escola de Enfermagem de Ribeirão Preto da Universidade de São Paulo, para obtenção do título de Mestre. Área de concentração: Enfermagem Psiquiátrica

Data da defesa:

\section{BANCA EXAMINADORA}

Profa. Dra. Antonia Regina Ferreira Furegato

Instituição:

Assinatura:

Prof. Dr.

Instituição:

Assinatura:

Prof. Dr.

Instituição:

Assinatura: 


\section{DEDICATÓRIA}

Aos meus pais Edson e Valdir e minhas mães Teresa e Francisca. Novamente repito o que disse, quando orador, na colação de grau: Deus deu-me a oportunidade de conviver com duas mães e dois pais num mundo tão carente de afetos, a vocês sou muito grato por me permitir caminhar pelos estudos e por ser o que sou hoje.

Aos meus irmãos Delbia e Heverton, por partilharem comigo o amor de nossos pais

e pelo constante apoio na minha caminhada.

Aos meus sobrinhos Ryan, Rayssa e Ray, ainda que a distância tenha nos separado, pelos momentos de alegrias que partilhamos.

Ao meu avô Antonio Bueno, que aos noventa anos me ensina que a vida jamais deixou de valer a pena.

E aos meus queridos tios Elídio e Adelina(in memorian). Ainda que na distância de um mundo intocável, pela saudade e por tudo o que significaram. 


\section{AGRADECIMENTOS}

A Profa. Regina Furegato pela oportunidade e orientação neste trabalho, com seu conhecimento, sua paciência e seu humanismo. Por me mostrar outras possibilidades, num momento tão importante e delicado da minha formação pessoal e profissional.

A Profa. Edilaine pela grande contribuição neste trabalho, pela impagável paciência e carinho para com minha pessoa nos momentos mais difíceis.

Ao Prof. Jair por sua contribuição na analise estatística e no banco de dados deste trabalho.

Aos Professores Pedrão e Sueli Galera pelas contribuições na qualificação deste estudo, e pelo apoio e incentivo na minha vida profissional e pessoal.

A Profa. Toyoko pela paciência nas conversas, pelos "puxões de orelha", pelas orientações para a vida e pelo incentivo.

A Gilda pelo carinho com que fui recebido e pela contribuição na execução deste trabalho.

Ao Departamento de Enfermagem Psiquiátrica e Ciências Humanas, pela oportunidade e pelo apoio, e a secretaria da Pós-graduação pelo apoio.

Aos pacientes que participaram desta pesquisa, por compartilharem suas experiências e seus sentimentos. 
Ao Hospital Irmãos Penteado pelo apoio da administração e do comitê de ética para a execução deste trabalho. Em particular a equipe do Pronto Socorro, que tanto me incentivou e me acompanhou: Coordenadora Enfa. Tatiana, Coordenador Dr. Carlos Eduardo, aos Técnicos Fátima, Fernanda, Luiz e Conceição, e aos recepcionistas Ana Lúcia e José Roberto.

Aos irmãos que a USP me deu e que a distância não me tirou: Adriano, Ana Paula, Bruno, Eduardo, Fábio, Fabrício, Jamil e Leandro. Em particular ao Evandro e ao Sidney pelo incentivo e pelo acolhimento em suas casas em Ribeirão Preto. E aos amigos que Campinas me deu, Beto e Augusto.

Aos amigos da 46a Turma de Enfermagem pelo prazer do nosso encontro, pela amizade e companheirismo, mesmo que separados pela distância e pelo tempo. 


\section{RESUMO}

SANTOS, I.P. Avaliação da presença de depressão entre usuários de plantão noturno em unidade de emergência. 103f. Dissertação de Mestrado - Escola de Enfermagem de Ribeirão Preto, Universidade de São Paulo, 2008.

A depressão pode ser considerada um problema de saúde pública devido aos agravos e perdas sociais conseqüentes. É um problema que por si já debilita a pessoa, levando a pior evolução, se assim estiver associada a alguma doença clínica. Freqüentemente é negada pelo próprio indivíduo por questões de preconceito social, visto provocar queda na produtividade pessoal, perda de iniciativa e de interesse. Este estudo objetivou conhecer a presença de depressão entre usuários de plantão noturno em unidade de emergência de uma instituição privada, relacionando esse fato aos condicionantes clínicos e biopsicossociais. Metodologia: A pesquisa foi realizada com 62 pacientes adultos que passaram por atendimento durante o período noturno, em casos que não envolviam situação de risco iminente de vida, no Pronto Socorro do Hospital Irmãos Penteado, uma instituição privada de assistência em saúde no município de Campinas-SP, nos meses de outubro e novembro de 2007. Foram aplicados dois instrumentos durante a entrevista: a) Identificação, informações clínicas e contextualização psicossocial; b) Inventário de Depressão de Beck. Os dados foram analisados estatisticamente por análise bivariada e multivariada pelo teste de Fisher. Os resultados mostraram que a amostra era composta por maioria de mulheres (75\%), solteiras, brancas, com predomínio de faixa etária entre 18 e 30 anos, bom nível educacional, com mais de $20 \%$ em nível superior e nenhum analfabeto; todos declaravam alguma ocupação, sendo destaque para comércio e administrativo, boa satisfação com moradia e salienta-se que todos os pacientes possuem convenio de saúde, seja pela empresa em que trabalham, seja porque pagam paralelamente. Entre as queixas clínicas mais comuns apareceram cefaléia como sintoma prevalente e problemas do sistema digestivo. Mais de $12 \%$ já tiveram diagnóstico anterior de depressão. Maioria pratica atividade física. Mais de 23\% apresentavam hipertensão leve, moderada ou severa durante o atendimento. Mais de $77 \%$ relataram dormir entre 6 e 8 horas diárias, mas quase metade alega problemas de sono. Estresse no trabalho e problemas relacionados a ele apareceram com certa freqüência. Álcool também chamou atenção, pois $45,2 \%$ alegavam fazer uso, mesmo que socialmente, enquanto que problemas com álcool ou drogas na família foram relatados para quase 20 $\%$. A depressão apareceu em $21 \%$ dos entrevistados, sendo $8,1 \%$ moderada, $12,9 \%$ leve e não houve depressão grave. O Inventário de Beck mostrou-se eficaz e chamou a atenção negativamente nos itens prazer, autocrítica, irritabilidade, sono, cansaço e preocupação com a saúde. Os dados mostraram correlação negativa para os itens hábito de fumar $(p=0,021)$, insônia $(p=0,005)$ e problemas econômicos $(p<0,000)$. Conclui-se que sintomas depressivos estavam aumentados se comparados à amostra não diagnosticada e insuspeita, mas em acordo com os dados de depressão associadas a outras doenças clínicas em hospital geral, qualquer patologia pode aumentar a prevalência de sintomas depressivos e vice versa. Essas informações permitem conhecer melhor o cliente atendido neste serviço de saúde e demonstra que ações de enfermagem em Emergência e Pronto Socorro podem e precisam ser pensadas a fim de garantir a integridade da pessoa que sofre psíquica e fisicamente, tendo em vista que cabe ao hospital geral atender as descompensações antes designadas exclusivamente aos serviços manicomiais. Sugerem-se estudos mais detalhados a fim de elucidar melhor a relação entre "estresse no trabalho", manifestação clínica e/ou somática e sintomas depressivos, bem como o fator "problemas econômicos" e impacto econômico, a fim de despertar o interesse das grandes empresas privadas de assistência a saúde para com a temática da saúde mental e incentivar a melhoria da assistência de pacientes, sejam conveniados ou não.

Palavras-chave: depressão, enfermagem, serviços médicos de emergência, sintomas clínicos, aspectos psicossociais. 


\begin{abstract}
SANTOS, I.P. Evaluation of the presence of depression among night call users at emergency room. 103f. Master dissertation - University of São Paulo at Ribeirão Preto College of Nursing, 2008.
\end{abstract}

Depression may be considered a public health problem due to consequential aggravation and social losses. It is a problem by its own and it weakens the person, leading to worse development, if associated with any clinical disease. Often it is denied by the individual himself for social prejudice issues, since it provokes drop in personal productivity, loss of initiative and interest. This study aimed to know the presence of depression among night call users at a private institution emergency unit, relating this fact to clinical and biopsycho-social indicators. Method: The research was conducted with 62 adult patients who have undergone care during the night time, in cases not involving imminent risk of life situations, in the Emergency Unity of Hospital Irmãos Penteado, which is a health care private institution, in the city of Campinas-SP, in October and November 2007. Two instruments were applied during the interview: a) Identification, clinical information and psychosocial contextualization b) Beck Depression Inventory. Data were statistically analyzed by bivariate analyses and multivariate by Fisher test. The results showed that the sample was composed by a majority of women $(75 \%)$, single, white, with predominance of age between 18 and 30 years, good educational level, with more than $20 \%$ with third degree and no illiterate; all declared any occupation, emphasizing trade and administrative jobs, good housing satisfaction and noting that all patients have health care insure, by the company where they work, or because they pay in parallel. Among the most common clinical complaints appeared headache as prevalent symptom and digestive system problems. More than $12 \%$ have had previous diagnosis of depression. Majority practices physical activity. More than $23 \%$ had mild, moderate or severe hypertension during care. More than 77\% reported sleeping between 6 and 8 hours a day, but nearly half claims sleep problems. Stress at work and problems related to it appeared with some frequency. Alcohol also drew attention because $45.2 \%$ claimed to use, even if socially, while alcohol or drugs problems in the family were reported to almost $20 \%$. The depression appeared in $21 \%$ of interviewees, with $8.1 \%$ moderate, $12.9 \%$ mild and no severe depression. Beck Inventory proved to be effective and drew attention negatively on items pleasure, self-criticism, irritability, sleep, tiredness and health concern. Data showed negative correlation for items smoking habit $(p=0021)$, insomnia $(p=0005)$ and economic problems $(p<0000)$. It is concluded that depressive symptoms were increased when compared to the undiagnosed and unsuspected sample, but in accordance with data of depression associated with other clinical diseases in general hospital, any pathology can increase the prevalence of depressive symptoms and vice versa. This information allows to better know the client attended at this health care service and demonstrates that nursing actions in Emergency and First Aid can and must be designed in order to ensure the integrity of the person who suffers psychically and physically, facing that it is up to the general hospital to attend the decompensations once exclusively designated to asylum services. More detailed studies are suggested to better clarify the relationship between "stress at work," clinical and/or somatic manifestation and depressive symptoms, and the factor "economic problems" in economic impact, in order to arouse the interest of large health care private companies in the mental health issue and to encourage the improvement in caring of patients, are they insured or not.

Keywords: depression, nursing, emergency medical services, clinical symptoms, psychosocial aspects. 


\section{RESUMEN}

SANTOS, I.P. Evaluación de la presencia de depresión entre usuarios de guardia nocturna en unidad de emergencia. 103f. Disertación para Grado de Master - Escuela de Enfermería de Ribeirão Preto, Universidad de São Paulo, 2008.

La depresión se puede considerar un problema de salud pública debido a los daños y pérdidas sociales consecuentes. Es un problema que por sí solo debilita a la persona, llevando a peor evolución, en el caso de estar asociada a una enfermedad clínica. Frecuentemente es negada por el propio individuo, debido a cuestiones de prejuicio social, debito al hacho que provoca reducción de la productividad personal, pérdida de iniciativa y de interés. Este estudio tuvo como objetivo el conocer la presencia de la depresión entre usuarios de guardia nocturna en unidad de emergencia de una institución privada, relacionando tal hecho a los condicionantes clínicos y biopsicosociales. Metodología: La investigación se llevó a cabo en 62 pacientes adultos que pasaron por atención durante el periodo nocturno, en casos que no involucraban situación de riesgo inminente de vida, en el Socorro de Urgencia del Hospital Irmãos Penteado, una institución privada de asistencia a la salud en la ciudad de Campinas-SP, durante dos meses de octubre y noviembre de 2007. Se aplicaron dos instrumentos durante la entrevista: a) Identificación, informaciones clínicas y determinación del contexto psicossocial; b) Inventario de Depresión de Beck. Los datos se analizaron estadísticamente por análisis bi-variada y multi-variada por medio de la prueba de Fisher. Los resultados mostraron que la muestra estaba compuesta por una mayoría de mujeres $(75 \%)$, solteras, blancas, con predominio de grupo de edad entre 18 y 30 años, buen nivel de educación, destacándose el comercio y administración, buena satisfacción con la vivienda y se destaca que todos los pacientes cuentan con seguro de salud, ya sea a través de la empresa donde trabaja, o por pagarlo en paralelo. Entre las quejas clínicas más comunes surgieron la cefalea como un síntoma predominante y problemas del sistema digestivo. Más de $12 \%$ ya tuvieron diagnóstico anterior de depresión. La mayoría practica actividad física. Más de $23 \%$ presentaban hipertensión leve, moderada o severa durante la atención. Más de 77\% relataron dormir entre 6 y 8 horas diarias, no obstante casi la mitad alega problemas de sueño. Estrés en el trabajo y problemas a él relacionados surgieron con cierta frecuencia. El alcohol también llamó la atención, ya que $45,2 \%$ alegaban hacer uso, aunque socialmente, mientras que casi un $20 \%$ relató problemas con alcohol o drogas en la familia. La depresión se manifestó en $21 \%$ de los entrevistados, siendo $8,1 \%$ moderada, $12,9 \%$ leve y no se encontró depresión grave. El Inventario de Beck se mostró eficaz y llamó la atención negativamente en los tópicos de placer, autocrítica, irritabilidad, sueño, cansancio y preocupación con la salud. Los datos mostraron correlación negativa para los tópicos hábito de fumar $(p=0,021)$, insomnio $(p=0,005)$ y problemas económicos $(p<0,000)$. Se concluye que síntomas depresivos estaban aumentados si comparados a la muestra no diagnosticada y no sospechosa, pero de acuerdo con los datos de depresión asociados a otras enfermedades clínicas en hospital general, cualquier patología puede aumentar la predominancia de síntomas depresivos y viceversa. Esas informaciones permiten conocer mejor al cliente atendido en este servicio de salud y demuestran que acciones de enfermería en Emergencia y en Socorro de Urgencia pueden y deben ser pensadas a fin de asegurar la integridad de la persona que sufre psíquica y físicamente, teniendo en cuenta que le cabe al hospital general atender a las descompensaciones antes designadas exclusivamente a los servicios de manicomios. Se sugieren estudios más detallados para elucidar mejor la relación entre "estrés en el trabajo", manifestación clínica y/o somática y síntomas depresivos, así como el factor "problemas económicos" e impacto económico, a fin de despertar el interés de las grandes empresas privadas de asistencia a la salud hacia el tema de la salud mental e incentivar la mejoría de la asistencia de pacientes, ya sean asegurados o no.

Palabras clave: depresión, enfermería, servicios médicos de emergencia, síntomas clínicos, aspectos psicosociales. 


\section{LISTA DE TABELAS}

Tabela 1 Distribuição dos dados sociodemográficos dos pacientes atendidos no Pronto Socorro, durante o

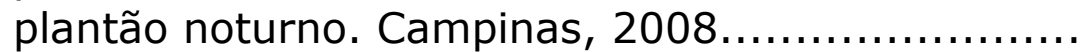

Tabela 2 Distribuição das informações clínicas dos pacientes atendidos no Pronto Socorro durante o plantão noturno. Campinas, 2008 .

Tabela 3 Distribuição das informações referentes à contextualização psicossocial dos pacientes atendidos no Pronto Socorro durante o plantão

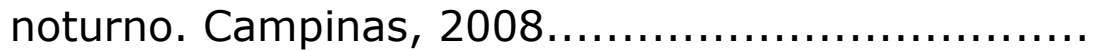

Tabela 4 Distribuição da freqüência de depressão entre usuários atendidos no Pronto Socorro, durante o

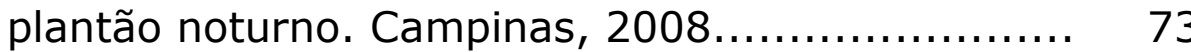

Tabela 5 Distribuição da freqüência de depressão segundo as variáveis independentes e significância do Teste de Fisher em pacientes atendidos no Pronto Socorro durante o plantão noturno. Campinas, 2008 


\section{SUMÁRIO}

II - REFERENCIAL TEÓRICO......................................................... $\quad 19$

1 - Conceituando Pronto Socorro e Pronto Atendimento......................... 20

2 - Conceituando Depressão................................................ 24

3 - Considerações Psicológicas para a Depressão............................. 34

a - Abordagem Comportamental........................................ 35

b - Abordagem Cognitiva............................................... 39

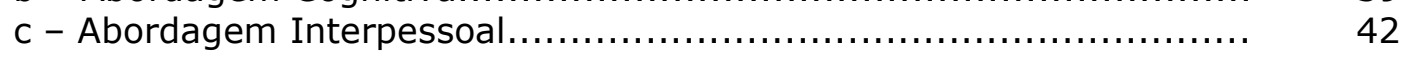

$d$ - Abordagem Construtivista ........................................ 43

4 - Fatores associados à Depressão.......................................... 45

III - OBJETIVOS........................................................................ 50

IV - METODOLOGIA .......................................................................... $\quad 51$

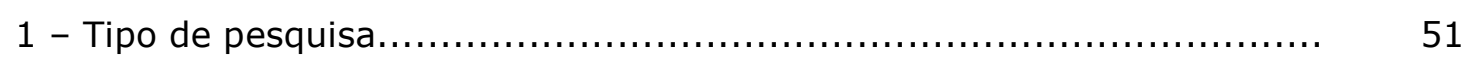

2 - Local do estudo..................................................... 51

3 - População e amostra................................................ 54

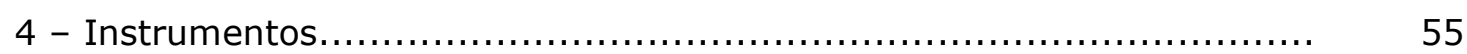

a - Identificação dos sujeitos da pesquisa............................... 55

b - Considerações sobre o Inventário de Beck........................... 56

$5-$ Aspectos éticos.......................................................... 58

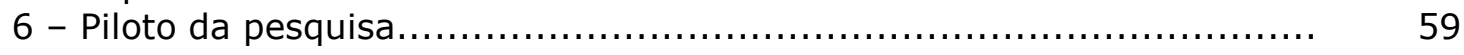

7 - Procedimento para coleta dos dados.................................... 59

8 - Procedimento para análise dos dados.................................... 61

V - RESULTADOS.............................................................................. $\quad 62$

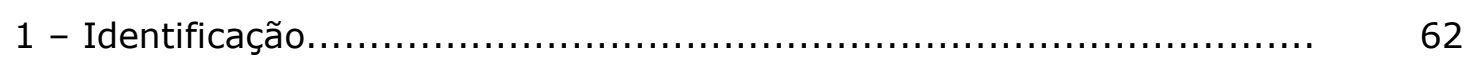

2 - Informações clínicas................................................. 65

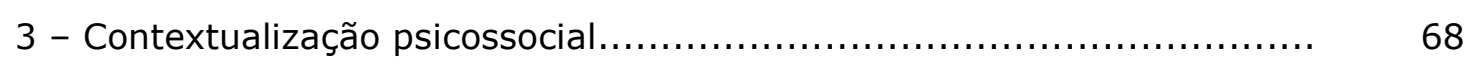

4 - Presença de depressão entre os entrevistados......................... 72

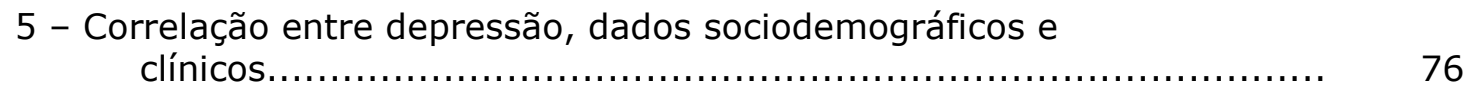

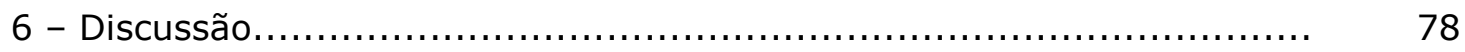

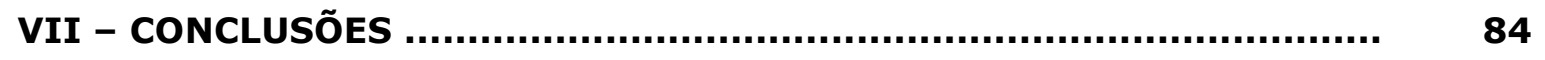

VIII - BIBLIOGRAFIA ......................................................... 87

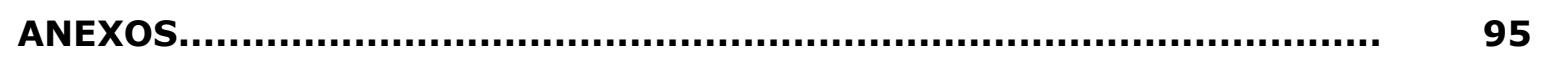




\section{I - INTRODUÇAO}

Durante o curso de graduação em enfermagem, aprendendo as bases da formação do enfermeiro, reforçava-se a idéia de enxergar o indivíduo como um todo, holisticamente. Essa visão ia pouco além do discurso. Não só o domínio da técnica é fragmentado, como o ser humano é visto muito mais como uma máquina biológica do que toda a sua pluralidade sócio-psico-espiritual.

Nightingale (1989), precursora da enfermagem moderna, deixa claro que a preocupação com o conforto do paciente é algo fundamental para o restabelecimento de sua saúde. A doença, para ela, era entendida como um processo restaurador da natureza, portanto, pensar em conforto, seria pensar em conforto mental também.

Desde os primórdios da enfermagem como profissão, enfatiza-se que o homem precisa ser visto como um todo, não podendo ser dividido como entidades fisiológica e psicológica. Entendida como prática social, a enfermagem vem participando do trabalho da saúde, vinculada a diversas outras práticas, mas que, necessariamente, para ser uma prática completa e social não pode excluir a saúde mental (ALMEIDA, 1986).

O doente mental sempre esteve entre nós e, portanto, a historia da enfermagem vem sendo traçada desde que 0 homem apresentou problemas de saúde, sendo que a dor psíquica é concomitante à existência humana (FUREGATO, 1999). 
Assim, os enfermeiros, não podem deixar de pensar na saúde mental dos pacientes, como parte de sua recuperação, como parte da manifestação de sua existência, ainda que rotineiramente não haja "preocupação", especialmente nos hospitais gerais com os problemas mentais dos pacientes.

Pensar na prática profissional da enfermagem, já atuando como enfermeiro, me fez caminhar para uma investigação na área de saúde mental em hospital geral, porque percebia que a questão psíquica para o hospital geral é na maioria das vezes sublimada, seja pelo modelo de tratamento biomédico estabelecido, seja porque as condições sociais do trabalho estão assim impostas. Mas o que levou-me a investigar em saúde mental, sendo eu atuante de um hospital geral, lidando com clínica médica, clínica cirúrgica e doenças que à primeira vista acometem o corpo? Como dar apoio psicológico ao paciente, que a mim foi ensinado como graduando, se isso ainda é tão mal elucidado para a própria graduação?

Furegato (1999) esclarece que o apoio psicológico, que é também entendido como atitudes compreensivas para com o paciente, vem sendo questionado pela enfermagem, pois não tem sido muito útil na ajuda com os pacientes, já que o próprio enfermeiro esbarra na falta de compreensão do que seja "dar apoio psicológico".

Pensar em assistência de enfermagem num hospital geral faz-se necessário, pois o sofrimento psicológico está presente em qualquer pessoa que vivencia um sofrimento. O sofrimento psicológico é um estado 
de desconforto associado a alguma ameaça à integridade da pessoa como ser biopsicossocial, envolvendo a construção de significados pessoais, acompanhados de forte carga afetiva, passíveis de modificar esse sofrimento (ROSAS, 1998).

A saúde mental no Brasil e a reforma psiquiátrica, não podem ser compreendidas como pontuais, porque sempre se praticou reformas ao longo de todas as mudanças no tratamento da doença mental, e toda mudança pode ser entendida como reforma. A reforma que tenha talvez ganho mais destaque, seria a reforma que acontece desde o final dos anos 70 no Brasil, em grande parte movida pela redemocratização política no país, onde o resgate da cidadania era imperativo, incluindo o resgate da cidadania do louco, que estava confinado nos manicômios (TENÓRIO, 2002).

O confinamento até então praticado era também identificado como institucionalização, isolamento do louco, considerado desviante de uma sociedade "racional". Entretanto, esse procedimento levava à cronicidade da doença, pelo tratamento impessoal, pelo abuso de psicofármacos, o distanciamento social e familiar (MACHADO, 2004).

Desde os anos 70, vem ocorrendo um movimento na América Latina e no Brasil, para direcionar propostas de reformulação e reorganização das políticas de saúde mental buscando humanizar o tratamento aos pacientes especialmente na rede pública de saúde. No entanto, muitas instituições psiquiátricas não passavam de empresas de saúde, revestidas 
de um saber psiquiátrico, usando o paciente com a finalidade de lucro em nome da ordem social (MACHADO, 2004).

Entre 1973 e 1982, foram divulgados documentos oficiais do Instituto Nacional de Previdência Social (INPS), Ministério da Previdência e Assistência Social e Divisão Nacional de Saúde Mental, condenando o atendimento asilar. Um grupo que impulsionou as discussões acerca da desinstitucionalização foi o Movimento dos Trabalhadores em Saúde Mental, iniciado na década de 1970 com a intenção de lutar "contra a privatização da saúde, dadas as particularidades e deformações do sistema psiquiátrico brasileiro" (MACHADO, 2004).

A partir desse processo de desinstitucionalização psiquiátrica, segundo Machado (2004) e Tenório (2002), o doente, antes institucionalizado e afastado completamente do convívio social, na busca de sua cidadania, se viu em tentativas de reinserção social; antes chamado de incapaz, por ser considerado louco, agora se vê presente em todos os setores da sociedade, para exercer essa cidadania, seja pelo trabalho, seja por outra ação social.

Para Tenório (2002), além desse papel individual de cidadania, houve tentativas de transpor a idéia de que se existe uma doença mental, também existiria uma saúde mental, e que se essa saúde fosse praticada, não haveria, ou diminuiria a manifestação das possíveis doenças mentais. Assim, propuseram a participação comunitária ou preventiva que o autor descreve como tentativas frustradas de "psicanalizar" a sociedade, mas que certamente deixaram seu viés, suas raízes, influenciando a concepção 
de doença mental bem como a certeza de que é preciso manter um padrão de saúde mental da mesma forma que a saúde física.

Para Almeida (1986), Mendes (1991) e Furegato (1999) a atuação de enfermagem não está limitada ao ambiente hospitalar. Sofre influência de diversas linhas de pensamento, muito fortemente pelas ciências sociais, porque é entendida como prática social. A prática da enfermagem é mais abrangentemente compreendida se pensada como assistência, pesquisa e ensino, porque assim a enfermagem o é. Como afirma Travelbee (1982), a atenção em enfermagem psiquiátrica deve ser oferecida em todos os lugares, escolas, comunidades e centros de saúde, sendo uma parte da prática de enfermagem. Portanto, uma assistência que visa a qualidade do atendimento ao individuo, faz-se necessário que todos os enfermeiros busquem conhecimentos não só na clínica psiquiátrica, mas também em saúde mental, em enfermagem psiquiátrica e áreas afins.

Para Minzoni et al (1977), sendo a saúde mental um componente essencial da saúde, reforça a idéia de dever do enfermeiro, como cuidador do indivíduo sob a ótica do direito humano. Ainda com Travelbee (1982), a enfermagem psiquiátrica e a enfermagem geral formam uma unidade, um todo, e nesse todo funciona o organismo psíquico e físico.

Como aluno do Programa de Pós-Graduação em Enfermagem Psiquiátrica da Escola de Enfermagem de Ribeirão Preto da Universidade de São Paulo, e atuando como enfermeiro em uma Unidade de Emergência e Pronto Atendimento, busquei subsídios para elaborar uma 
pesquisa que contemplasse essas questões e práticas, cujos resultados pudessem contribuir para o atual contexto da assistência de enfermagem à saúde das pessoas seja sob a ótica clínica, seja pela ótica da saúde mental.

Escolhi a depressão como possibilidade a ser estudada dentro de minha prática profissional porque, atuando como enfermeiro de um pronto socorro vinculado a um hospital geral privado, o contato se dá com esse paciente de forma rápida, mas nesse tempo seria cabível e necessário, ainda que curto, que permitisse uma assistência a fim de perceber esse cliente o mais integralmente possível.

Além disso, a depressão contempla as questões anteriormente discutidas, do paciente portador de um transtorno psiquiátrico vindo a um hospital geral, da idéia de sanitarismo frente às questões mentais, além de associar uma investigação que aparentemente pode ser clínica, mas que vem imbuída de sentimentos psicológicos e problemas sociais.

Também é interessante notar que o local onde a pesquisa foi realizada, por se tratar de um hospital privado, atendendo somente pacientes conveniados e particulares, estaria percebendo a clientela como massa trabalhadora, onde esses pacientes atendidos mantêm o convênio por se tratar de plano empresa. Assim, seria possível observar nos sintomas depressivos das pessoas ali atendidas, quando existissem, quanto aos conceitos de perdas profissionais, sociais e econômicas (WILLIANS et al, 1999; OPAS/OMS, 2001; MAJ e SARTORIUS, 2005; SADOCK e SADOCK, 2007). 
Assim, tenho em mente as seguintes reflexões:

- A reforma psiquiátrica afetou os atendimentos e cuidados de enfermagem nos hospitais gerais, tendo em vista que não cabe apenas ao manicômio "resolver o problema" do doente mental na sociedade.

- Essas idéias do sanitarismo e da reforma têm reflexos sobre os clientes, antes atendidos como "normais".

- As pessoas que procuram atendimento clínico em Unidade de Emergência ou Pronto Socorro apresentam associação de problemas emocionais e comportamentais. 


\section{II - REFERENCIAL TEÓRICO}

O paciente psiquiátrico não está mais contido em ambientes antes chamados de manicômios. Ele está inserido na sociedade e desta participa, inclusive como força de trabalho e também é forte a idéia de que a higiene mental precisa ser mantida na nossa sociedade.

Dados da Organização Mundial da Saúde (OMS) estimam que cerca de 450 milhões de pessoas sofram de transtornos mentais ou comportamentais, representando $12 \%$ da carga mundial de doenças, sendo que apenas uma ínfima minoria dessas pessoas recebe tratamento adequado, quando muito o mais básico (OPAS/OMS, 2001).

Nessas leituras depara-se com um quadro que, de certa forma, está sendo observado e estudado pela comunidade científica atualmente: a depressão. Entre outras tantas manifestações humanas, este tema chama a atenção por se tratar de uma manifestação que debilita a pessoa, que está associada a um sofrimento muitas vezes clínico, ou que se manifesta como tal. É frequentemente negada pelo próprio indivíduo que a vivencia, por estar carregada de preconceito, tendo em vista que ela provoca queda na produtividade do indivíduo, perda de iniciativa e de interesse (SILVA et al. 2003; FURLANETO e BRASIL, 2006; SADOCK e SADOCK, 2007). 


\section{1 - Conceituando Pronto Socorro e Pronto Atendimento}

As unidades de emergência são locais apropriados para o atendimento de pacientes com afecções agudas onde existe um trabalho de equipe especializada e podem ser divididas em: pronto atendimento, pronto socorro e emergência (GOMES, 1994).

O pronto atendimento é definido como a unidade destinada a prestar, dentro do horário de funcionamento do estabelecimento de saúde, assistência a doentes, com ou sem risco de vida, cujos agravos à saúde necessitam de atendimento imediato (BRASIL, 1985).

O pronto socorro é o estabelecimento de saúde destinado a prestar assistência a doentes, com ou sem risco de vida, cujos agravos a saúde necessitam de atendimento imediato, funcionando nas 24 horas do dia com apenas leitos de observação (BRASIL, 1985).

Emergência é a unidade destinada à assistência de doentes, com ou sem risco de vida, cujos agravos necessitam de atendimento imediato, funcionando nas 24 horas com leitos de observação e que mantenha vinculo com unidade hospitalar para procedimentos de maiores complexidades como cirurgias e exames de alta complexidade (BRASIL, 1985).

Importante salientar que segundo Rodríguez (2000), a emergência passou pouco a pouco a representar socialmente a idéia de consulta médica rápida, com perfil de atendimento de ambulatório de 
especialidades, em partes pela saturação do sistema de cuidados primários em saúde. Mas este autor ainda adverte que emergência se remete a cuidados especializados imediatos que evitem, assim, a morte ou complicações graves no indivíduo, estando estes serviços preparados para situações deste tipo. Aqui se encontraria uma origem da massificação dos serviços de emergência, dos atrasos na assistência urgente e no aumento do nível de estresse do pessoal que trabalha nesses mesmos serviços. Isto no caso do sistema público, pois o sistema privado ainda que com uma configuração semelhante, tem uma demanda muito menor.

Segundo Wehbe e Galvão (2001), são funções assistenciais do enfermeiro com relação às unidades de emergência, pronto atendimento e pronto socorro:

- Prestar o cuidado ao paciente juntamente com o médico

- Preparar e ministrar medicamento

- Viabilizar a execução de exames especiais procedendo à coleta

- Instalar sondas nasogástricas, nasoenterais e vesicais em pacientes

- Realizar troca de traqueostomia e punção venosa com cateter

- Efetuar curativos de maior complexidade

- Preparar instrumentos para intubação, aspiração, monitoramento cardíaco e desfibrilação, auxiliando a conduta médica na execução dos procedimentos diversos

- Realizar o controle dos sinais vitais

- Executar a evolução dos pacientes e anota em seus prontuários

- Realizar a estatística dos atendimentos ocorridos na unidade 
- Liderar a equipe de enfermagem no atendimento dos pacientes críticos e não críticos

- Coordenar as atividades do pessoal de recepção, limpeza e portaria

- Solucionar problemas decorrentes com o atendimento médicoambulatorial

- Alocar pessoal e recursos materiais necessários

- Realizar a escala diária e mensal da equipe de enfermagem

- Controlar estoque de material

- Verificar a necessidade de manutenção dos equipamentos do setor.

Segundo Wehbe e Galvão (2001), cabe ainda à equipe de enfermagem que compreende os técnicos e auxiliares trabalhando sob supervisão do enfermeiro:

- Realizar a pré-consulta

- Verificar os sinais vitais e anotar a queixa atual do paciente que fez com que procurasse o serviço de saúde

- Acomodar o paciente na sala de urgência ou sala de curativos, caso seja necessário

- Instalar soroterapia, sondagem vesical e nasogástrica

- Administrar medicamentos via intramuscular, endovenosa e oral quando prescritos

- Preparar o material de sutura e circular a sala de procedimentos para o mesmo 
- Preparar o material e auxilia a equipe médica em caso de punção de subclávia ou jugular interna, ou mesmo na dessecação de veia

- Encaminha o paciente ao RX e exames complementares

A liderança é fundamental para o trabalho do enfermeiro de serviços de urgência, emergência, pronto socorro e pronto atendimento, sendo necessárias como características desejáveis nesse líder: a comunicação, bom conhecimento na clínica, profissionalismo e habilidade em incentivar sua equipe. Para que o enfermeiro efetivamente exerça uma liderança eficaz, é necessário que esse profissional conheça a si mesmo e conheça as necessidades e expectativas pessoais e profissionais dos membros de sua equipe de enfermagem (WEHBE e GALVÃO, 2001)

A enfermagem psiquiátrica situa-se no contexto das emergências, segundo Kapczinski et al (2001), na medida em que a reforma psiquiátrica, o processo de desinstitucionalização e o fechamento de vários hospitais psiquiátricos do tipo "manicomiais", levaram a um aumento do número de pacientes sujeitos a descompensações na comunidade. Nesse processo se inseriu o serviço de emergência psiquiátrica especificamente, a fim de servir de interface entre a comunidade e as instituições de tratamento de saúde mental, tendo em vista que as internações passaram a ser muito criteriosas e a internação integral passando a ser mais uma opção, e não a única, de tratamento, dividindo essa tarefa com serviços extra-hospitalares como hospitais-dia, pensões protegidas e ambulatórios. 
Outrossim, atender uma situação de emergência em um pronto socorro que envolva risco ou tentativa de suicídio, delírios, agressividade e agitação, pode sabidamente estar envolvido em um caso de depressão, entre outras coisas. Cabe à equipe de emergência estar atenta ao processo para garantir a segurança da pessoa que sofre e a qualidade da assistência a ela prestada, bem como garantir seu tratamento contínuo ao atendimento na situação de emergência.

\section{2 - Conceituando Depressão}

A DEPRESSAO é definida como um constructo diagnóstico complexo aplicado a indivíduos com um conjunto particular de sintomas, sendo os principais o humor deprimido e a perda de interesse (MAJ e SARTORIUS, 2005). É uma doença incapacitante, que interfere de modo decisivo e intenso na vida pessoal e profissional, social e econômica das pessoas acometidas, sendo também apontada como uma das epidemias do século.

A Organização Mundial de Saúde (OMS) afirma que $20 \%$ da população mundial um dia padecerá deste mal. As mudanças na vida sócio-econômicas das últimas décadas geraram no homem uma série de problemas, que de certa forma se manifestaram no aumento de doenças mentais (PEREIRA 1998, OPAS/OMS 1999, LAFER et al 2000, DALGALARONDO 2000, SILVA 2003).

Para Lafer et al (2000), a depressão atinge de 15 a 20\% da população em algum momento de suas vidas. Com estimativa de $15 \%$ dos 
deprimidos graves com risco de suicídio. Ainda com esses autores, em São Paulo, dados da década de 1990 mostraram que aproximadamente $16 \%$ da população apresentava pelo menos um episódio depressivo ao longo da vida.

A depressão é reconhecida como um problema de saúde pública que para a OMS, em 1990 a depressão maior unipolar foi a principal causa de "anos vivido com incapacitação" em países desenvolvidos, e que em 2020 será também a maior causa em mulheres e em países em desenvolvimento. Em suma, depressão é um transtorno mental comum que gera um ônus de doença muito elevado e deverá mostrar uma tendência ascendente nos próximos 20 anos (OPAS/OMS, 2001).

No Brasil, segundo Dalgalarrondo (2000), em torno de 31 a 50\% da população brasileira apresenta durante a vida pelo menos um episódio de transtorno mental, e cerca de 20 a $40 \%$ da população necessita, por conta desses transtornos, de algum tipo de ajuda profissional, o que justifica o estudo da depressão e a necessidade de seu reconhecimento e de assistência adequada.

A depressão pode ser entendida como queda ou redução da função, considerada pela psiquiatria como tristeza extrema, melancolia ou abatimento, podendo ser sintoma de algum transtorno psiquiátrico ou a manifestação primordial de uma reação psicótica depressiva ou de uma neurose. Para Burguess (1981), abrange grande número de comportamentos tanto de indivíduos considerados normais como de indivíduos com problemas clínicos ou psiquiátricos. 
É também interessante notar que autores como Teixeira (1993) e Lafer et al (2000) afirmam que o termo depressão pode comportar pelo menos três significados: sintoma, síndrome, e entidade nosológica (doença). O sintoma pode surgir nos mais variados quadros clínicos dentre os quais: transtorno de estresse pós-traumático, demência, esquizofrenia, alcoolismo ou doenças clínicas, ou também como resposta a situações estressantes ou a circunstâncias sociais e econômicas adversas. Como síndrome, inclui não apenas alterações de humor como tristeza, irritabilidade, falta de capacidade de sentir prazer, apatia, mas uma gama de outros aspectos, incluindo alterações cognitivas, psicomotoras e vegetativas, como sono e apetite, considerando que ela pode acompanhar doenças sistêmicas, neurológicas e/ou neuropsiquiátricas. Em se tratando de doença, a depressão tem sido classificada de várias formas, na dependência do período histórico, da preferência dos autores e do ponto de vista adotado. O paciente deprimido sofre de intenso sentimento de culpa, tem idéias depreciativas sobre si mesmo e falsas crenças que o levam a acusar-se de inúmeros delitos. Essas manifestações de comportamento podem acometer tanto indivíduos considerados normais como aqueles com problemas psiquiátricos.

A característica mais marcante da doença é a tristeza, associada à dificuldade em resolver conflitos do dia-a-dia, diminuição da atividade, idéias de culpa ou de ruína e sentimentos de incapacidade e inferioridade (MERENESS, 1973; BURGUESS, 1981). 
Segundo Lafer et al (2000), todas as pessoas passam por momentos de dificuldades, nos quais se sentem tristes, sozinhas, infelizes. $\mathrm{Na}$ maioria das vezes a pessoa está experimentando um sentimento normal e absolutamente compreensível, pois, o sofrimento é uma condição da existência humana, e nem sempre a queixa comum de estar deprimido significa um processo patológico e nem se constituirá em objeto de estudo da psicopatologia.

Entretanto, a literatura relata estudos onde $50 \%$ dos pacientes deprimidos que buscam atenção primária permanecem sem ser diagnosticados e sem receber tratamento, repercutindo em uma carga excessiva de sofrimento, elevada morbidade e mortalidade, e um contínuo risco de suicídios (MONTGOMERY, 1997).

Além disso, as formas moderadas de depressão podem se apresentar mascaradas. O cliente procura ajuda profissional e tem como queixa principal uma dor de cabeça persistente, uma dispepsia com falta de apetite, constipação ou gosto ruim na boca e não ser investigada a possibilidade de se configurar num quadro de depressão (D'ANDREA, 1986).

Entretanto, uma depressão diagnosticada e tratada precocemente, pode ser resolvida mais rapidamente e não causar tantos prejuízos aos indivíduos acometidos, evitando a cronificação da doença e, principalmente, o suicídio. Uma característica peculiar da depressão é que acomete principalmente adultos jovens, entre 20 e 30 anos, atingindo 
duas vezes mais mulheres que homens, sem haver um consenso dos pesquisadores quanto a esse dado (FRAGUAS JUNIOR et al, 2002).

As características psicopatológicas da depressão nos pacientes com doença clínica são diferentes daquelas encontradas em pacientes com depressão primariamente psiquiátrica. Isto decorre, provavelmente, devido a fatores emocionais, físicos e psicológicos diretamente ligados à doença clínica à qual a depressão está associada. Além disso, alguns sintomas depressivos como insônia, diminuição da concentração, inapetência, emagrecimento e fraqueza são encontrados em outras doenças não psiquiátricas e podem ser atribuídos exclusivamente a estas, e o diagnóstico de depressão não ser realizado. O diagnóstico precoce e tratamento é essencial, uma vez que além do comprometimento da qualidade de vida, a depressão acarreta significativo aumento da morbidade e mortalidade decorrentes da condição médica. Dentre os vários comprometimentos já descritos, a depressão pode aumentar o tempo de internação, aumentar o risco de taquicardia ventricular, aumentar a mortalidade no pós-operatório ou após o infarto agudo do miocárdio, diminuir a adesão ao tratamento e à reabilitação, e, em cardiopatas, constituir um dos principais fatores de risco para complicações cardíacas (FRAGUAS JUNIOR et al, 2002).

É sabido também que a grande maioria das equipes de atenção à saúde, não estão preparadas para prestar atenção à saúde mental das pessoas, mais especificamente à depressão onde, na maioria dos casos, nem é feito o diagnóstico (SILVA et al, 2003). É tarefa da equipe de saúde 
reconhecer as manifestações de comportamento do cliente, estando ciente que depressão pode ir de um grau leve até um estado de profundo abatimento ou desinteresse pela vida. Assistir o indivíduo deprimido com qualidade e eficiência é compromisso ético de todos os profissionais, pois somente com atenção adequada é que os profissionais estarão cuidando e preservando a vida das pessoas (TEIXEIRA, 1993).

Nos aspectos históricos da depressão, encontra-se a sua descrição tanto na Grécia antiga, em Ilíada, de Homero, como no antigo testamento com o Rei Saul numa história de síndrome depressiva (SADOCK e SADOCK, 2007). Hipócrates também foi um dos primeiros a relatar a melancolia, descrevendo-a como um estado de aversão à comida, insônia, irritabilidade e inquietude. Acreditava-se ainda que esta pessoa estava sob influência de Saturno, e que secretavam "bile negra" a qual enegrecia o humor influenciando o cérebro. Este termo "bile negra" continuou sendo usado por muitos outros autores médicos até o século VI.

No início do século XIX, Esquirol descreveu vários casos delirantes de melancolia e dois de seus discípulos, Falret e Baillarger, cunharam a expressão loucura circular para o que hoje denomina-se de transtorno bipolar do humor, que seria depressão e mania na mesma pessoa (SADOCK e SADOCK, 2007).

Em 1882, o psiquiatra alemão Karl Kahlbaum, usou o termo "ciclotimia", que descreve a mania e a depressão como estágios da mesma doença. $\mathrm{Na}$ passagem entre os séculos $\mathrm{XIX}$ e XX, estudos desenvolvidos por Emil Kraepelin tiveram contribuições fundamentais na 
caracterização dos quadros do humor como entidades nosológicas, descrevendo uma psicose maníaco-depressiva que continha a maioria dos critérios usados atualmente pelos psiquiatras, para o estabelecimento do diagnóstico que hoje é chamado de transtorno bipolar I (SADOCK e SADOCK, 2007).

Hoje, a depressão é classificada como um transtorno de humor. Mas ainda no inicio do séc.XX, Adolf Neyer cunhou o termo psicobiologia dos transtornos mentais para considerar não somente aspectos biológicos, mas psicológicos, preferindo o termo depressão à melancolia uma vez que o último não contemplava os aspectos biológicos. Na década de 40, Cade demonstrou a eficácia do lítio no tratamento dos quadros de mania aguda, e Schou mais tarde demonstra que o lítio também era eficaz na profilaxia do transtorno bipolar. No final da década de 50, ocorreu um interesse redobrado nos aspectos biológicos dos transtornos mentais com a introdução da clorpromazina para o tratamento de quadros psicóticos e de agitação grave. Também nesta década surgiram os antidepressivos tricíclicos, tendo como hipótese de que além de sua ação anticolinérgica, bloqueava a recaptação pré-sináptica noradrenérgica (SADOCK e SADOCK, 2007).

Na década de 70, Van Praag e colaboradores apud Sadock e Sadock, (2007) postularam a disfunção neuroquímica em oposição à tradicional nosológica. A partir da década de 80 , as ações terapêuticas de longa duração dos antidepressivos em nível intracelular na pós-sinapse foram sendo elucidadas. Finalmente, na década de 90, a ênfase maior tem sido 
dada aos mecanismos nucleares (moleculares), dos efeitos dos antidepressivos, abrindo um novo campo no entendimento da depressão bem como para novas formas de tratamentos. Atualmente, os estudos etiológicos são direcionados para um modelo integrativo que abrange aspectos neuroquímicos, neuorimunológicos e neuroendócrinos, como também, psicobiológicos e ambientais (SADOCK e SADOCK, 2007).

Atualmente, a literatura traz as definições dos seguintes quadros em depressão: Transtorno depressivo maior, distimia, depressão integrante do transtorno bipolar I e II, depressão como parte da ciclotimia (CID - 10, 1997; WILLIANS, FRANN e STRASSER, 1999; LAFER et al, 2000; DALGALARRONDO, 2000). As diferenças entre os transtornos de humor, anteriormente reconhecidas na clínica foram verificadas e são oficialmente reconhecidas pela quarta edição do Manual Diagnóstico e Estatístico de Transtornos Mentais (DSM - IV, 1994). Incluem-se, nesta edição, algumas alterações como: o acréscimo de um critério de que o transtorno tem causado um comprometimento no funcionamento social ou ocupacional ou acentuado sofrimento para o paciente e também o nome do transtorno foi alterado, de depressão maior para transtorno depressivo maior (SADOCK e SADOCK, 2007).

Segundo Willians, Frann e Strasser (1999), estas desordens depressivas representam a mais comum condição ocupacional de saúde que os enfermeiros podem experimentar e a mais comum desordem entre as doenças mentais. 
Para Sadock e Sadock (2007), os principais transtornos do humor são o transtorno depressivo maior e o transtorno bipolar I. Estes, na maioria das vezes, são chamados de transtornos afetivos, entretanto a patologia crítica nesses transtornos é do humor, o estado interno mais constante de uma pessoa. Os pacientes que apresentam apenas episódios depressivos podem ter um transtorno depressivo maior, também chamado ocasionalmente de depressão unipolar. Já os pacientes com episódios maníacos e depressivos e pacientes apenas com episódios maníacos têm transtorno bipolar I. Há dois transtornos do humor adicionais: o distímico e o ciclotímico, caracterizados pela presença de sintomas menos severos que os sintomas de transtorno depressivo maior e transtorno bipolar I.

No DSM - IV (1994) aparecem os transtornos do humor adicionais que incluem síndromes relacionadas à depressão como: transtorno depressivo menor, transtorno depressivo breve recorrente e transtorno disfórico pré-menstrual, bem como transtorno bipolar II, que para Sadock e Sadock (2007), a gravidade do sintoma não alcança a intensidade necessária para um diagnóstico de transtorno depressivo maior, no caso do transtorno depressivo menor. No transtorno depressivo breve recorrente, os episódios depressivos alcançam a severidade para um diagnóstico de transtorno depressivo maior, mas o fazem apenas por um breve período; no transtorno bipolar II se caracteriza a presença de episódios depressivos maiores alternando com episódios de hipomania, isto é, episódios de sintomas maníacos que não reúnem todos os critérios para episódios maníacos vistos no bipolar I. 
O humor pode ser normal, elevado ou deprimido, sendo que a maioria das pessoas classificadas como "normais" experimentam ampla faixa dos humores e têm um repertório igualmente variado de expressões afetivas, sentindo-se no controle, mais ou menos, de seus humores e afetos. O humor elevado (mania), mostra expansividade, fuga de idéias, sono diminuído, auto-estima elevada e idéias grandiosas. O humor deprimido (depressão) é acompanhado de perda de energia e interesse, sentimentos de culpa, dificuldades para concentrar-se, perda do apetite e pensamentos sobre morte e suicídio. Ainda incluem-se alterações nos níveis de atividade, capacidades cognitivas, linguagem e funções vegetativas como sono, apetite, atividade sexual entre outros ritmos biológicos, comprometendo o funcionamento interpessoal, social e ocupacional (OPAS/OMS, 2001; SADOCK e SADOCK, 2007).

Apesar do National Institute of Mental Health (NIMH) ter iniciado um programa para aumentar a conscientização da depressão entre a população em geral e entre os médicos, os sintomas de depressão, freqüentemente, são impropriamente considerados como reações compreensíveis ao estresse, evidências de fraqueza de caráter ou, simplesmente, como uma tentativa consciente de obter algum ganho secundário (SADOCK e SADOCK, 2007).

Considerando-se de fundamental importância o presente estudo como feed-back para a instituição onde foi aplicado, a fim de avaliar as suas condições de resolutibilidade e de atenção ao cliente que a procura, para os sintomas descritos ou não, entendendo também que a depressão 
é um problema de ordem econômica visto que esta leva a deterioração da produtividade e do crescimento do uso dos serviços de saúde, no caso um serviço de saúde privado.

Willians, Frann e Strasser (1999), analisando o impacto econômico da depressão numa empresa examinaram os dados de desabilitados, os custos/benefícios de saúde, e o programa de assistência aos funcionários $(E A P)$, comparando a depressão com outras doenças. Referem que a depressão tem determinado maior custo/benefício médico de todos os comportamentos das condições de saúde e foi o diagnóstico mais comum no EAP. Resultando em muitos dias de desabilitação e em doze vezes mais recidivas do que doenças crônicas como cardiopatias, hipertensão e diabetes, representando $52 \%$ de todos os pedidos dos planos médicos aos cuidados da saúde comportamental para funcionários, esposas e dependentes.

\section{3 - Considerações Psicológicas para a Depressão}

Para Ito e Lotufo Neto (2000) as abordagens teóricas da depressão, vieram do interesse crescente pela investigação dos aspectos psicológicos dos transtornos depressivos nos últimos 20 anos, tanto pelo desenvolvimento de teorias que se destacaram por sua abordagem empírica, contribuindo para uma melhor compreensão desse transtorno, bem como para o seu tratamento. 


\section{a - Abordagem Comportamental}

Numa revisão desses aspectos, Ito e Lotufo Neto (2000) citam:

- Modelo de ausência de reforço, que foi proposto por Lewinsohn apud Ito e Lotufo Neto (2000), afirmando que sintomas depressivos podem resultar da diminuição ou ausência de reforço positivo nas interações do indivíduo com o ambiente; o reforço positivo ocorre como contingente da conseqüência do comportamento da pessoa. Mas se determinados comportamentos não gerarem, ou raramente produzirem este reforço positivo, o indivíduo tende a reduzir significativamente suas atividades e interações de recompensa, podendo facilitar o surgimento de sintomas depressivos, como isolamento, perda de interesse e disforia. $\mathrm{Na}$ ânsia dos familiares, em ajudar este indivíduo, dando-Ihe mais atenção e diminuindo as exigências sobre sua responsabilidade, reforçam a redução das atividades da pessoa aumentando o comportamento e o humor deprimido, gerando um ciclo vicioso.

Nesta abordagem é importante considerar que, estados depressivos compoem um continuum, onde inatividade e infelicidade podem variar de leves a graves, cabendo aqui a depressão como um transtorno psiquiátrico influenciada por diferenças individuais, variáveis biológicas, sexo e idade. Coyne apud Ito e Lotufo Neto (2000) concluiu que experiências estressantes tornam indivíduos deprimidos mais propensos a pedir ajuda aos outros, e que esse padrão de demanda pode ser aversivo para as demais pessoas, resultando em rejeição, hostilidade, 
aborrecimento e culpa nas interações, além de diminuir o grau de reforço positivo no ambiente.

- No Modelo de solução de problemas, em Ito e Lotufo Neto (2000), o conceito é definido sob várias perspectivas. Pelo ponto de vista comportamental é uma forma de aprendizagem, onde a resposta do indivíduo a um problema constitui uma mudança de comportamento. $\mathrm{Na}$ aprendizagem social, um processo onde 0 indivíduo orienta as características de seu comportamento na direção de um resultado desejado, para que em termos de saúde mental seja uma estratégia onde o objetivo é descobrir uma ampla gama de comportamentos eficazes que contribuem para a facilitação e manutenção da competência social geral.

Com Nezu, Nezu e Perri apud Ito e Lotufo Neto (2000), no modelo da solução de problemas, a depressão pode resultar da interação de eventos vitais negativos, problemas atuais, manejo de estratégias para solução de problemas e sintomatologia depressiva, essa interação é ainda influenciada por fatores genéticos, vulnerabilidade biológica e história prévia, incluindo desenvolvimento e aprendizagem. Tanto um evento vital negativo, como ser despedido, implica na procura de um novo emprego, redução de gastos, dificuldades familiares e sociais, baixa auto-estima, etc, e problemas rotineiros podem levar a mudanças importantes na vida, como no caso de uma dificuldade de comunicação com o parceiro resultar em divórcio. Tanto um evento vital negativo como um problema do dia-adia são estressores que podem potencialmente produzir várias 
conseqüências negativas e requerem certo grau de esforço para serem manejadas com sucesso (ITO e LOTUFO NETO, 2000).

Essas conseqüências negativas podem tornar as pessoas vulneráveis a episódios depressivos, e a percepção de negatividade depende da importância dos seus efeitos para o indivíduo, o qual por sua vez, é influenciado pela história de aprendizagem, objetivos pessoais e circunstância atual de vida. Quanto maior o tempo de duração dos problemas, maior a probabilidade de ocorrência de depressão clínica. Por outro lado, lidar com sucesso na solução de problemas, pode eliminar, ou diminuir o desconforto emocional negativo imediato e prevenir reações afetivas em longo prazo (ITO e LOTUFO NETO, 2000).

-Para o Modelo de desamparo aprendido, é necessário esclarecer que este modelo foi estabelecido a partir de estudos de Seligman apud Ito e Lotuffo Neto (2000), onde cachorros foram submetidos a choques elétricos inescapáveis no início, mas que não emitiam nenhuma resposta em fases posteriores, submetendo-se passivamente aos choques, mesmo quando podiam controlar a emissão desses, não apresentando quaisquer sinais de emoção, bem como déficits de motivação, de aprendizagem e de emoções. Este estado foi definido pelos autores como desamparo, e posteriormente utilizado como um modelo para a depressão em humanos.

Seligman apud Ito e Lotuffo Neto (2000) comparou as respostas de indivíduos com sentimentos de desamparo, manipulados em experimentos em laboratório, com o comportamento de indivíduos que sofriam de depressão. Os dois grupos demonstraram padrões de resposta 
semelhante, incluindo passividade, retardo na aprendizagem, redução da agressividade, perda de apetite, expectativas negativas e sentimento de desamparo, desesperança e impotência. Esse estudo também indicou que experiências com resultados incontroláveis produziam comportamento do tipo depressivo em desempenhos subseqüentes. Entretanto, críticas foram feitas a esse modelo, a ausência de consideração aos fatores relacionados à gravidade e cronicidade da doença e à distinção entre as diversas categorias de depressão, além da incapacidade para explicar sintomas proeminentes da depressão como culpa e autopunição, sendo inconsistente dizer que pessoas se autopuniriam por eventos sobre os quais acreditariam não ter controle.

Posteriormente, Abramson, Seligman e Teasdale apud Ito e Lotuffo Neto (2000) reformularam a teoria do desamparo, dando maior ênfase aos aspectos cognitivos, destacando-se a interpretação causal individual sobre eventos incontroláveis. Neste modelo revisado, os autores postulam que a atribuição determina a ação e o afeto do indivíduo, e que, portanto o comportamento e a emoção são consistentes com a interpretação dos eventos. Apresentam três dimensões relevantes para a compreensão do papel da interpretação sobre um determinado evento: 1) a causa pode ser atribuída à pessoa ou à situação (interna ou externa); 2) a causa pode ser vista como um fator que será transitório ou persistente no tempo (instável ou estável); 3) a causa pode ser percebida como tendo um impacto sobre uma variedade de acontecimentos futuros ou estar limitada apenas ao evento (global ou específica). 
Para Ito e Lotufo Neto (2000), é importante considerar que as explicações causais e o estilo explicativo não são por si mesmos suficientes para determinar a depressão; são fatores de risco que aumentam a probabilidade de que a pessoa se sinta deprimida ou em desamparo, frente a eventos negativos.

\section{b. Abordagem Cognitiva}

Ainda com Ito e Lotufo Neto (2000), até a década de 70, a psiquiatria considerava a disfunção cognitiva e comportamental de pacientes com depressão como conseqüência de um distúrbio primário de humor. Essa visão foi modificada devido ao enfoque dado nos estudos de Beck, Ellis e Meinchenbaum apud Ito e Lotufo Neto (2000) os quais demonstraram que os pensamentos negativos de pacientes deprimidos não são apenas um mero sintoma, mas um fator importante na manutenção do quadro clínico. A grande contribuição desses modelos para o tratamento da depressão foi a constatação de que muitos sintomas depressivos poderiam ser reduzidos através da identificação e modificação dos pensamentos negativos dos pacientes. Dentro dessa abordagem então temos:

- Modelo racional-emotivo: parte da premissa de que as pessoas são afetadas negativamente pelos acontecimentos, em função da atribuição que dão aos mesmos, ou seja, sentimentos mal-adaptativos 
resultam de pensamentos mal-adaptados (ELLIS apud Ito e Lotuffo Neto, 2000).

Não há razões legítimas para que os seres humanos necessitem sentir-se aborrecidos ou emocionalmente perturbados frente a eventos negativos de qualquer natureza, baseado no estoicismo. No entanto, quando emoções auto-depreciativas e inapropriadas, como culpa, depressão, ansiedade e raiva ocorrem, adicionam-se automaticamente ao sistema de valores uma hipótese não verificada de que as próprias ações ou as das demais pessoas são repreensíveis e inaceitáveis. Essas idéias compõem uma filosofia irracional de vida a que indivíduo se propõe, sendo essa, muitas vezes, a causa de problemas emocionais e de sintomas físicos. Não importa quando ou como o indivíduo adquiriu uma filosofia irracional de vida, mas a manutenção de tal filosofia produz sentimentos de depreciação e decepção em relação a si mesmo e ao mundo externo (ITO e LOTUFO NETO, 2000).

- Modelo de auto-instrução: propõe que padrões disfuncionais de pensamentos e diálogos internos mal-adaptados podem facilitar a ocorrência de transtornos de humor. Um diálogo interno com conteúdo auto-depreciativo pode ao longo do tempo produzir desconforto subjetivo e interferir na adequação do desempenho do indivíduo, podendo contribuir para o surgimento de sintomas depressivos (ITO e LOTUFO NETO, 2000).

- Modelo de reestruturação cognitiva: parte dos estudos de Beck (1997) e Beck et al (1997), propõe que a experiência pessoal nos leva a formar pressupostos sobre nós mesmos, o mundo e o futuro, os 
quais são, de acordo com a teoria, armazenados como estruturas cognitivas ou esquemas. Compõe o sistema de valores e crenças e auxilia na previsão de atitudes e no sentido dado às experiências pessoais, fundamental ao funcionamento normal.

Um pressuposto disfuncional em si não causa depressão, mas dificuldades podem surgir quando um evento crítico se encaixa perfeitamente com o sistema de valores da pessoa. Uma vez ativados, os pressupostos disfuncionais produzem pensamentos negativos automáticos (PNA), que estão associados a emoções desagradáveis e invadem a mente da pessoa, sem um esforço deliberado, interferindo nas interpretações de experiências atuais, previsões sobre eventos futuros, ou lembranças de fatos passados, afetando diversas áreas de funcionamento como: o comportamento - diminuição das atividades; a motivação - perda de interesse; as emoções - ansiedade e culpa; a cognição - indecisão e dificuldade para se concentrar e o físico - perda de apetite e sono. Quanto mais deprimida a pessoa, maior a ocorrência de pensamentos negativos, e maior a crença sobre a veracidade desses pensamentos e, quanto mais pensamentos negativos e maior essa crença sobre sua veracidade, mais deprimida a pessoa se torna (BECK, 197; BECK et al, 1997).

Beck et al (1997) propõem que a manutenção de esquemas depressivos é uma conseqüência de falha no sistema de processamento de informação, onde o indivíduo extrai conclusões ilógicas derivadas de seis erros cognitivos básicos: 1) inferência arbitrária - chegar a uma conclusão específica na ausência de evidências que dêem suporte para tal 
conclusão; 2) abstração seletiva - chegar a uma conclusão com base em um detalhe fora do contexto; 3) supergeneralização - chegar a uma conclusão global e ampla, com base em um ou outro aspecto isolado da informação; 4) magnificação e minimização - exagero no significado de eventos negativos e minimização do significado de eventos positivos; 5) personalização - relacionar a ocorrência de eventos externos a si próprio, na ausência de uma base realista para tal conexão; 6) pensamento absolutista e dicotômico - colocar todas as experiências em uma ou duas categorias opostas. Indivíduos deprimidos, ao cometerem esses erros de lógica, terão pensamentos caracterizados como extremos, negativos, categóricos, absolutos e preconceituosos. Tal percepção distorcida serve para manter a visão negativa acerca de si, do mundo e do futuro.

Este modelo ainda enfatiza que a distorção de informações, não é em si anormal. A depressão distorce, exagera e intensifica um processo presente em todos nós. A cognição distorcida é um dos aspectos responsáveis pela manutenção da depressão, onde a interação de fatores como o biológico, o social e o psicológico parecem contribuir para a predisposição e início de um episódio depressivo (BECK et al, 1997).

\section{c. Abordagem Interpessoal}

Para Ito e Lotufo Neto (2000), a psicoterapia interpessoal foi desenvolvida nos últimos 20/25 anos para ser usada em estudos científicos sobre a eficácia do tratamento de depressão. Sua base empírica 
está nas observações feitas acerca dos vínculos humanos, onde emoções mais intensas estão relacionadas à formação, ruptura ou renovação destes, como amizade, romance, casamento, divórcio, relacionamento mãe-criança. A presença de relacionamentos interpessoais próximos e satisfatórios auxilia na prevenção de depressão, ao passo que a ruptura destes tem papel importante no desenvolvimento de depressão. Pacientes deprimidos têm menos amigos, apoio e interações prazerosas com outros, além de isolamento social e conflitos conjugais ocorrerem com alta freqüência antes do início da depressão.

Acreditando como Furegato (1999) e Ito e Lotufo Neto (2000), que o cuidado se dá basicamente através das relações interpessoais, o aprendizado em enfermagem deve levar em conta que o ser humano é fruto de um constructo bio-psico-socio-espiritual, mais do que uma abordagem teórica. A psicoterapia individual foi planejada como um tratamento psicológico específico para atender às necessidades de pacientes deprimidos, enfatizando os relacionamentos interpessoais, sem deixar de lado o papel da genética, da neurobiologia, da bioquímica, do desenvolvimento e estrutura da personalidade na causa e vulnerabilidade à depressão.

\section{d. Abordagem Construtivista}

Para Ito e Lotufo Neto (2000), a psicoterapia construtivista é útil, pois permite trocas e negociações sutis e diversificadas de significados 
pessoais ou interpessoais, articulando, elaborando e revisando os constructos que o cliente usa para organizar sua experiência e ação. Num nível abstrato, este trabalho envolve unir-se ao cliente para desenvolver um mapa detalhado dos constructos que frequentemente não são articulados, nos quais há investimento emocional e que definem os cursos de ação, para então procurar ampliar o número de mundos possíveis que ele possa habitar.

Do ponto de vista construtivista, o ser humano não tem acesso à realidade imediata além da linguagem que Ihe é fornecida pela cultura. Esta condição existencial questiona o conhecimento, conduzindo à proliferação de realidades diversas e contraditórias. Apesar de não poder aspirar a um conhecimento válido que corresponda ao mundo real externo à pessoa, pode e deve utilizar os recursos simbólicos do seu tempo e lugar para formular teorias viáveis ou ficções úteis que lhe permita negociar com o mundo social, antecipar adequadamente os eventos, dar sentido a vida e prover esquemas organizadores pragmáticos e úteis para guiar a ação humana, constituindo um sistema de significados ou teorias pessoais que definem o senso de identidade da pessoa e o modo de relação com os outros (ITO e LOTUFO NETO, 2000). Nesta relação, os níveis de intervenção são profundos, focalizando os processos pessoais básicos que mantêm o senso de identidade individual e o relacionamento essencial com os outros.

O objetivo deste tipo de terapia é criar uma atmosfera pessoal e interpessoal, onde os problemas apresentados possam ser resolvidos e 
reformulados na linguagem, onde os clientes possam ter validadas novas identidades com menos problemas, num estilo mais personalizado e não autoritário, onde a meta é a criatividade e não a corretividade, não aceitando o discurso objetivista, resistindo a prescrições metodológicas; porém, não desconsidera o espaço da pesquisa na clínica (ITO e LOTUFO NETO, 2000).

\section{4 - Fatores Associados à Depressão}

Os fatores que se apresentam associados à depressão estão em estudo. Apesar de não haver evidencias claras, alguns fatores se apresentam da seguinte forma:

- Sexo: mulheres são duas vezes mais acometidas pela depressão unipolar do que os homens; alguns indicativos mostram que o ciclo feminino pode estar relacionado a presença de depressão e também é uma relação socialmente construída (NIEVAS, FUREGATO E SANTOS, 2006; JUSTO e CALIL, 2006). Afeta pelo menos $12 \%$ das mulheres e $8 \%$ dos homens em algum momento da vida para as formas depressivas segundo Sadock e Sadock (2007).

- Idade: estudos têm demonstrado que indivíduos jovens relatam mais frequentemente história de depressão maior do que os idosos. Adultos referem aparecimento dos sintomas depressivos em idades bem mais precoces (SILVA FUREGATO 
E COSTA, 2003). Os riscos de transtornos emocionais de qualquer tipo em países desenvolvidos são maiores entre 25 e 44 anos, por ser considerado um período de estresse, e menor na meia idade. Sugerem-se observar fatores ambientais, urbanização, mudanças na estrutura familiar entre outros (BEE, 1997). Não há consenso para fator idade, os trabalhos têm seu foco na presença dos sintomas depressivos, até porque estudos dizem que pessoas com mais de 65 anos relatam menos frequentemente disforia ou anedonia do que as pessoas mais jovens (LAFER et al, 2000).

- Para Raça, não há na literatura algo que indique uma prevalência numa raça ou noutra. O problema está na tendência dos examinadores em não diagnosticar ou diagnosticar demasiadamente em pacientes que tem antecedentes raciais ou culturais diferentes dos seus (SADOCK e SADOCK, 2007).

- Estado Civil é fator interessante, pois a depressão unipolar ocorre mais frequentemente em pessoas que não têm relações interpessoais íntimas ou são divorciadas ou separadas. Entre divorciados e solteiros, o transtorno bipolar pode ser mais comum do que em casados, refletindo o aparecimento precoce e a resultante discórdia conjugal, que são características dessa perturbação (SADOCK e SADOCK, 2007). 
- No Nível Sócio-Econômico e Cultural, alguns dados na literatura mostram diminuição da prevalência de vários transtornos psiquiátricos, incluindo a depressão com o aumento da renda e da educação (BURVILL, 1995), mas Sadock e Sadock (2007), consideram que não existe uma correlação entre situação socioeconômica, aparecendo entre grupos possivelmente por causa de práticas diagnósticas tendenciosas.

Para Montgomery (1997), a depressão acaba se tornando um transtorno difícil de identificar e diagnosticar tendo em vista três fatores que por serem complexos podem gerar essa falsa percepção do problema: 1 - fatores do paciente; 2 - fatores do médico e 3 - fatores mascarantes.

Montgomery (1997) ainda refere que a entrevista no caso de suspeita de depressão, precisa levar em conta que sua duração e dedicação serão adequadas se efetuar uma evolução diagnóstica minuciosa. O que percebemos que na maioria das vezes não acontece, pois nossa prática de atenção em saúde gira em torno da produção em série, de volumes absurdos de atendimentos com quantidades ínfimas de profissionais, que nem sempre estão capacitados para tal identificação e conduta.

Segundo Arroyo (2007), o tempo de consulta é fator fundamental na percepção da qualidade da assistência e do serviço percebidos pelo paciente. Demorar demais para ser atendido pode gerar muita ansiedade 
favorecendo avaliações negativas do serviço pelo paciente; se for rápido demais (inferior a 10 minutos) é maior a tendência do paciente perceber negativamente a qualidade do atendimento.

Muitos convivem com o estado depressivo por longo período de tempo sem procurar ajuda especializada, pois não sabem que seu estado é manifestação de uma doença que deve ser diagnosticada e adequadamente tratada. Pessoas simples ou mais esclarecidas e mesmo profissionais da área da saúde, têm em mente que o estado de tristeza e de desinteresse seja próprio de suas vidas ou da natureza da sua personalidade, chegando a crer que estão pagando por algum pecado ou saldando alguma culpa (FUREGATO et al, 2006).

A OPAS/OMS (2001) considera a prevenção, o tratamento e a reabilitação como ferramentas fundamentais no processo de manejo dos transtornos mentais. Enquanto enfermeiro da rede privada, e de um pronto socorro, considero que posso atuar na prevenção e tratamento adequado, sendo uma das minhas responsabilidades como facilitador da identificação precoce, encaminhamento e orientação. Entretanto, o que este projeto se propôs, a priori, foi a identificação dos sintomas depressivos em uma população específica, confrontando esses dados com a literatura, que a posteriori poderia gerar subsídios para outras implementações, em face da questão: demanda de atendimento e profissionais disponíveis.

Inclusive a própria OPAS/ OMS (2001) recomenda a importância do apoio à pesquisa em saúde mental a fim de melhorar a sua compreensão 
e desenvolver intervenções mais efetivas principalmente nos países em desenvolvimento.

Cabe ao enfermeiro, de formação crítica, perceber o quanto pode ajudar, e fazê-lo, independente de achar que trabalha em setor de saúde mental, numa UBS, ou unidade hospitalar de grande porte. Cabe a ele ir além dos conceitos populares de que depressão é doença mal vista "de quem não tem uma ocupação pra mente", de "gente desocupada" como comumente se escuta.

Frente ao que está disponível na literatura e a necessidade de oferecer o melhor cuidado ao deprimido, questiono como identificar sintomas, definir tratamentos e esperar resultados se não levarmos em conta a gama de fatores implicados na depressão?

Assim propus este estudo buscando subsídios para uma percepção que pudesse confrontar dados citados com a prática de uma unidade de emergência frente à presença de sintomatologia de depressão, bem como para usar estes conhecimentos obtidos da pesquisa e de mais aprofundamento nesta temática, promover a implementação mais adequada da assistência em saúde, numa visão holística do indivíduo, na tentativa de atender as suas reais necessidades. 


\section{III - OBJETIVOS}

Conhecer a presença de depressão em usuários do plantão noturno em uma unidade de emergência em instituição privada e relacionar este fato aos condicionantes clínicos e contextuais. 


\section{IV - METODOLOGIA}

\section{1 - Tipo de Pesquisa}

Esta pesquisa é um estudo exploratório descritivo. Acreditando, como Koizumi (1992) que o problema a ser estudado é o que determina o método a ser utilizado, escolhe-se a metodologia quantitativa, pois esta pesquisa se utilizou de procedimentos estruturados e de instrumentos formais, que permitiram identificar e reconhecer o sujeito da pesquisa, bem como identificar a presença de depressão.

\section{2 - Local do Estudo}

Este estudo foi realizado na Unidade de Emergência do Hospital Irmãos Penteado, localizado no município de Campinas, estado de São Paulo, cidade com mais de 1 milhão de habitantes, situada a $95 \mathrm{~km}$ da capital. Está entre as cidades brasileiras de maior importância comercial e social.

Este serviço foi escolhido pela relevância histórica que este hospital tem para Campinas, e pelas configurações descritas anteriormente, se tratando de uma unidade privada de assistência em urgências, emergências e pronto atendimento, caracterizando uma clientela atendida em grande parte por possuírem convênios de saúde por conta do vínculo empregatício que mantêm. 
Fundado em 1871, é um marco para a cidade, sendo o primeiro grande hospital campineiro, também conhecido como Santa Casa de Misericórdia de Campinas, sendo sua mantenedora a Irmandade de Misericórdia de Campinas. Teve papel importante no combate as grandes epidemias que alcançaram à cidade ao longo de mais de 135 anos de sua existência. Sediado em local privilegiado, na região central da cidade, arquitetura característica e papel de destaque social e educacional, visto que, por anos, foi espaço para a formação de mão de obra em saúde, incluindo uma parceria com a UNICAMP (Universidade de Campinas), que durou até a metade da década de 80 .

O Hospital Irmãos Penteado e a Santa Casa de Misericórdia de Campinas constituem um grande espaço físico, têm capacidade para 125 leitos incluindo clínicos, cirúrgicos, centro cirúrgico, pediatria, UTI, maternidade, pronto socorro e ambulatório. Atende a clientes particulares e conveniados para assistência de urgência, emergência, ambulatório e pronto atendimento, incluindo internações eletivas. Além disso, dispõe também de duas enfermarias, totalizando 53 leitos, mantidas pelo Sistema Único de Saúde (SUS), cujas vagas são controladas pelo sistema regulador de vagas da Secretária Municipal de Saúde. Entretanto, não há uma relação dessas vagas com o Pronto Socorro citado neste estudo.

Vale ressaltar também que a sua mantenedora, Irmandade de Misericórdia de Campinas consta registrado como entidade filantrópica, de prestação de serviço de cunho social, como acontece com as Santas Casas do país. Entretanto, o atendimento no Pronto Socorro do Hospital Irmãos 
Penteado, limita-se somente aos casos de pacientes que não possuem convênio de saúde privado onde haja uma emergência clínica com risco de vida, como forma legal da não negação de assistência de saúde para esses casos conforme prevê a lei.

O Pronto Socorro do Hospital Irmãos Penteado conta com quatro equipes:

- Manhã (corresponde das 07 às 13 hs): com 6 técnicos de enfermagem, 1 enfermeiro 2 recepcionistas e 1 médico clínico geral;

- Tarde (corresponde das 13 às 19 hs): com o mesmo número de funcionários da manhã;

- Uma equipe para cada noturno (corresponde das 19 as 07 do dia seguinte, alternadamente), chamada de noturno $1 \mathrm{e}$ noturno 2; dispõe de 1 enfermeiro, 4 técnicos de enfermagem, 2 recepcionistas e 1 médico clínico geral para cada equipe.

As equipes dos noturnos não contam com funcionário para cobrir folgas nem férias, o que se dá pelo meio da organização entre as equipes. A Unidade ainda conta com uma coordenadora de enfermagem que cumpre horário comercial, e de um coordenador médico que realiza plantões como clínico geral no próprio Pronto Socorro.

De todos os funcionários citados, todos têm vínculo empregatício com a entidade, regidos pela Consolidação das Leis do Trabalho (CLT) do 
Ministério do Trabalho, exceto os médicos que não têm esse vínculo, pois são autônomos, prestadores de serviço para a entidade.

\section{3 - População e Amostra}

Este serviço de Pronto Atendimento realiza cerca de 2500 atendimentos mensais. Desse total, 353 atendimentos foram observados durante a coleta de dados no período Noturno I, sendo que desses 353 foram entrevistados $62(17,6 \%)$ usuários nos mais diversos horários considerando o estabelecido pela pesquisa.

O atendimento se dá com o paciente chegando pela porta principal, entregando seus documentos e carteira do convênio à recepção, que elabora a ficha de atendimento em sistema informatizado, gerando uma ficha impressa dando início ao atendimento pela enfermagem. Esta realiza uma pré-consulta ou acolhimento, onde se verificam os sinais vitais do paciente, perguntando suas queixas clínicas e o motivo da procura pelo pronto atendimento, o que dependendo da sintomatologia deverá ser encaminhado para atendimento imediato em face da possibilidade de agravamento e risco, ou é pedido para que aguarde ser chamado pelo médico, que realizará a consulta, voltando o paciente para a enfermagem que medica e orienta conforme a prescrição médica. Assim, após esse processo o paciente é reavaliado pelo médico que libera este de alta, ou sendo o caso, solicita internação se necessário para a resolutividade do 
problema. Inclui-se aqui, a petição de exames complementares, seja de radiodiagnóstico ou laboratoriais.

A amostra estudada foi composta por 62 pacientes, maiores de idade, que tivessem condições físicas e clínicas de participar da entrevista, respondendo ao questionário verbalmente e tendo condições de ler e responder ao Inventário de Beck. Essas pessoas passavam em atendimento pelo Pronto Socorro no período noturno obrigatoriamente tendo em vista o objetivo deste estudo, compreendendo o horário das 19:00h às 07:00h do dia seguinte, que concordassem em participar da pesquisa, que não apresentassem risco de vida em sua abordagem clínica.

\section{4 - Instrumentos}

\section{a. Identificação dos sujeitos da pesquisa}

O instrumento de identificação dos sujeitos (Anexo 1), foi elaborado a fim de permitir uma descrição de 3 itens em detalhes:

- Identificação do sujeito

- Informações clínicas

- Contextualização psicossocial

Nas informações de identificação constam dados como idade, sexo, etnia, escolaridade, procedência, estado civil, arranjo domiciliar, ocupação e religião. 
Nas informações clínicas há espaço para sinais vitais, queixa apresentada para procura do serviço, medicações em uso, consultas anteriores, doenças crônicas, diagnóstico anterior de depressão, sono, atividade física, alimentação, hábitos e vícios e uso anterior de serviço de psicologia ou psiquiatria.

Importante salientar que a queixa com que chegou ao pronto socorro (informações clínicas), foi anotada e, após avaliação médica, era descrita no CID-10, sempre que possível.

Na contextualização psicossocial foram incluídos eventos marcantes, problemas de relacionamento, divórcio, problemas de ordem familiar, econômicos, aposentadoria, satisfação com moradia, mudança de residência, bem como uso de recursos da comunidade e lazer, além de ocupações voluntárias.

\section{b . Considerações sobre o Inventário de Beck}

O Inventário de Depressão de Beck (Anexo2), (Beck Depression Inventory - BDI; Beck et al, 1961), é provavelmente a medida de autoavaliação de depressão mais amplamente usada tanto em pesquisa como em clínica, tendo sido traduzido para vários idiomas e validado em diferentes países.

No Brasil sua tradução e validação para o português foi realizada por Gorenstein e Andrade (1996) numa população de estudantes universitários e vem sendo amplamente aplicado em pesquisas 
(GORESTEIN \& ANDRADE, 1998; OPAS/OMS, 1999; SILVA, FUREGATO E COSTA, 2003; FUREGATO et al, 2006).

Para Gorestein e Andrade (1998), o BDI não tem pretensão diagnóstica, mas foi desenvolvido para ser utilizado em populações de pacientes diagnosticados por meio de entrevistas clínicas, complementando a avaliação pela óptica do próprio paciente.

A escala original do BDI consiste em 21 itens, cada qual com 4 afirmações, incluindo sintomas e atitudes, cuja intensidade varia de 0 a 3, sendo zero o neutro e o três de intensidade máxima, permitindo refletir sobre a gravidade do sintoma, podendo as pontuações do questionário variar de 0 a 63 ao todo. Os itens referem-se à: tristeza, pessimismo, sensação de fracasso, falta de satisfação, sensação de culpa, sensação de punição, autodepreciação, autoacusações, idéias suicidas, crises de choro, irritabilidade, retração social, indecisão, distorção da imagem corporal, inibição para o trabalho, distúrbio de sono, fadiga, perda de apetite, perda de peso, preocupação somática e diminuição de libido (GORESTEIN e ANDRADE, 1998).

Há várias propostas com diferentes pontos de corte para distinguir os níveis de depressão utilizando o BDI. No caso deste estudo, levamos em conta que a amostra é não diagnosticada. Assim, as diretrizes para este tipo de amostra considera, segundo Steer et al (1987), Kendall et al (1987) e Gorestein e Andrade (1998), escores até 15 pontos como sem depressão, de 16 a 20 para disforia ou depressão leve, de 21 a 29 como depressão moderada e acima de 30 como depressão grave. 
Gorestein e Andrade (1998) completam que várias evidências de estudos apontam para a adequação da versão em português do BDI. Sendo que os padrões de respostas obtidos nas diferentes amostras são semelhantes aos observados com a versão original, bem como aos relatos de outros idiomas. A alta consistência interna da versão em português corrobora a validade de construto do questionário, sendo o BDI um instrumento útil para avaliar aspectos específicos de depressão em amostras não clínicas de adultos, o que deu segurança na escolha deste instrumento para a coleta dos dados do presente estudo.

\section{5 - Aspectos Éticos}

Seguindo os preceitos éticos e legais da pesquisa envolvendo seres humanos (Resolução 196/96), este projeto foi submetido ao Comitê de Ética em Pesquisa (CEP) da Escola de Enfermagem de Ribeirão Preto da Universidade de São Paulo, bem como submetido ao CEP do Hospital Irmãos Penteado, instituição onde foi desenvolvido após aprovação de ambos os comitês, bem como autorização dos coordenadores médico e de enfermagem do Pronto Socorro referido (Anexo 4, 5 e 6).

Além do consentimento pessoal dos entrevistados, para cada sujeito da pesquisa foi solicitada a colaboração com a explicação dos objetivos, do objeto de estudo, da forma de participação e do uso das informações por ele colhidas $e$, os que concordaram, assinaram o termo de Consentimento Livre e Esclarecido (Anexo 3). 


\section{6 - Piloto da pesquisa}

Antes da realização da coleta de dados propriamente dita, foi realizado um piloto com o intuito de servir para o pesquisador se familiarizar com os instrumentos aplicados, perceber o tempo necessário em cada entrevista, afim de não estendê-la em demasia, nem adiantá-la demais, bem como a melhor forma de abordagem, a diferenciação dos questionários e sua adequação.

Para tanto, foi realizada uma prévia de seis entrevistas, que não foram computadas nas 62 entrevistas totais. Dessas entrevistas do piloto o pesquisador concluiu que, dos dois instrumentos, o de identificação deveria ser aplicado primeiramente, como uma entrevista, permitindo um diálogo com o entrevistado, que gerava clima adequado para o segundo instrumento, o BDI, que era explicado, entregue e dado um tempo ao entrevistado, que reservadamente respondia. Este processo permitiu ao pesquisador perceber o tempo mais adequado ao fluxo de atividades no Pronto Socorro, não prejudicando o cliente que aguardava a consulta médica e não prejudicando a dinâmica do atendimento na Unidade, mas também não comprometendo a qualidade dos procedimentos da pesquisa.

\section{7 - Procedimentos para a coleta dos dados}

A coleta se deu no período de 16 de outubro de 2007 a 17 de novembro de 2007, intercalando os plantões alternadamente, conforme a 
escala de um enfermeiro do setor que prestasse serviço nesta unidade, em regime de $12 \mathrm{hs}$ de trabalho por 36 horas de descanso.

A cada entrevista eram explicados os objetivos da pesquisa, o objeto de estudo, a forma como a pessoa participaria deste estudo, bem como o uso das informações por ela cedidas e os instrumentos utilizados. A seguir, era lido o Termo de Consentimento Livre e Esclarecido, que, se concordassem, assinavam e começávamos a entrevista do Instrumento de Identificação. Posteriormente, era deixado o paciente na salinha de préconsulta respondendo o Inventário de Depressão de Beck por alguns minutos.

Foram aplicados os dois instrumentos aos pacientes atendidos no Pronto Socorro, seguindo a ordem de chegada, dada a maioridade do paciente, seu grau de lucidez e compreensão, e somente seria entrevistado um seguinte após ter se encerrado completamente a entrevista anterior, sendo excluídos aqueles que não se dispuserem a participar voluntariamente, que não apresentavam condições de ler, compreender e responder às questões, ainda os que estavam clinicamente impossibilitados de responder por se tratar de uma situação de urgência ou emergência, tendo em vista o local da pesquisa se tratar de um Pronto Socorro. 


\section{8 - Procedimento de análise dos dados}

Os dados referentes à Identificação dos sujeitos, às Informações clínicas e à Contextualização psicossocial foram submetidos à análise por estatística descritiva.

Os dados do BDI foram classificados segundo escore para os níveis de depressão e posteriormente submetidos à análise estatística para descrição da freqüência dos níveis de depressão apresentados pelos sujeitos da amostra. Foi realizada ainda a análise por questão do BDI, considerando-se a freqüência das respostas dadas a cada item da referida escala.

Os resultados foram analisados estatisticamente através da Análise bivariada e multivariada, comparando os sintomas indicativos de depressão com as variáveis hábitos (fumo, bebida), insônia, obesidade, hipertensão, sexo, atividade física, depressão anterior e problemas econômicos.

Análise bivariada: quando todas as variáveis de interesse são cruzadas com a variável Depressão, categorizada em "sem depressão" e "com depressão". Para cada cruzamento foi calculada a significância (P) do teste de Fisher (HOLLANDER e WOLFE, 1999).

Analise multivariada: é de suma importância, sendo que diante da multicausalidade e inter-relaçoes entre as variáveis, permite relativizar a importância de cada uma, na presença e sob a influência das demais (HOLLANDER e WOLFE, 1999). 


\section{V - RESULTADOS}

\section{1 - Identificação}

A idade dos 62 entrevistados variou de 18 a 56 anos, sendo 15 homens $(24,2 \%)$ e 47 mulheres $(75,8 \%)$, conforme se observa na tabela 1. A maior parte dessas pessoas $(48,3 \%)$ encontrava-se na faixa de 21 a 30 anos.

A amostra foi composta por maioria branca de 44 indivíduos (71,8\%). Havia 33 solteiros $(53,2 \%)$, e 35 moram sem companheiro (56,5\%). Observe que apenas 3 não tinham ensino médio completo, os demais $(74,2 \%)$ tinham completado o nível médio e $21 \%$ no nível superior. Grande parte dos sujeitos (48) é procedente de Campinas $(77,4 \%)$.

No que se refere à ocupação, por se tratar de uma resposta aberta, gerou muitas informações que foram agrupadas seguindo o critério abaixo:

- Comércio: auxiliar de comércio, callcenter, comissária de bordo, estoquista, promotor de vendas, seguros e sinistros, telemarketing e vendedora;

- Saúde: auxiliar de enfermagem, técnico de enfermagem, instrumentadora cirúrgica;

- Educação: professora; 
- Administrativo: assistente administrativo, atendente, auxiliar administrativo, bancária, caixa, cerimonial, contabilidade, escriturária, faturista, recepcionista;

- Indústria: auxiliar de controle de qualidade, auxiliar de produção, funcionário da "Petrobras";

- Serviços gerais: babá, copeira, cozinheira, empregada doméstica, mecânico, serviços gerais, vigilante, guarda municipal;

- Outros: do lar, estudante, estagiária, jornalista, sindicalista, aposentado.

Interessante notar que não aparece nenhum entrevistado que se declare sem ocupação ou na condição de desempregado, mesmo um aposentado (professor) se mantém trabalhando.

O hospital onde se localiza o pronto socorro atende somente a conveniados e particulares, o que por si só, cria uma condição de seletividade dessa clientela, podendo ser caracterizada como médio e alto poder aquisitivo. São economicamente ativos, já que grande parte desses atendimentos ocorre, pois o paciente tem o convênio de saúde como benefício da empresa pelo qual está registrado, ou mesmo porque pagam este convênio por iniciativa própria.

No que tange à religião $67,7 \%$ referem ser católicos, mas $58,1 \%$ do total alegam não praticar a sua religião e $83,9 \%$ alegam não terem mudado de religião. 
Tabela 1 - Distribuição dos dados sociodemográficos dos pacientes atendidos no Pronto Socorro, durante o plantão noturno. Campinas, 2008.

\begin{tabular}{|c|c|c|}
\hline Variável $(n=62)$ & Freqüência & $\%$ \\
\hline \multicolumn{3}{|l|}{ Sexo } \\
\hline Feminino & 47 & 24,2 \\
\hline Masculino & 15 & 75,8 \\
\hline \multicolumn{3}{|l|}{ Idade } \\
\hline Menos de 20 & 8 & 12,9 \\
\hline 21 a 30 & 30 & 48,3 \\
\hline 31 a 40 & 12 & 19,3 \\
\hline 41 a 50 & 7 & 11,4 \\
\hline 50 a 56 & 5 & 8,0 \\
\hline \multicolumn{3}{|l|}{ Estado Civil } \\
\hline Solteiro & 33 & 53,2 \\
\hline Casado & 23 & 37,1 \\
\hline Separado & 5 & 8,1 \\
\hline Viúvo & 1 & 1,6 \\
\hline \multicolumn{3}{|l|}{ Ocupação } \\
\hline Comércio & 11 & 17,7 \\
\hline Saúde & 7 & 11,3 \\
\hline Educação & 1 & 1,6 \\
\hline Administrativo & 19 & 30,6 \\
\hline Indústria & 4 & 6,5 \\
\hline Serviços & 4 & 6,5 \\
\hline Outros & 16 & 25,8 \\
\hline \multicolumn{3}{|l|}{ Religião } \\
\hline Católico & 42 & 67,7 \\
\hline Evangélico & 16 & 25,8 \\
\hline Espírita & 3 & 4,8 \\
\hline Outra & 1 & 1,6 \\
\hline \multicolumn{3}{|l|}{ Etnia } \\
\hline Branco & 44 & 71,8 \\
\hline Negro & 6 & 9,7 \\
\hline Pardo & 11 & 17,7 \\
\hline Amarelo & 1 & 1,6 \\
\hline \multicolumn{3}{|l|}{ Escolaridade } \\
\hline Ensino Médio Incompleto & 3 & 4,8 \\
\hline Ensino Médio Completo & 46 & 74,2 \\
\hline Ensino Superior Incompleto & 9 & 14,5 \\
\hline Ensino Superior Completo & 4 & 6,5 \\
\hline \multicolumn{3}{|l|}{ Arranjo domiciliar } \\
\hline Só & 3 & 4,8 \\
\hline Com outros, sem companheiro & 35 & 56,5 \\
\hline Com companheiro & 5 & 8,1 \\
\hline Com companheiro e outros & 19 & 30,6 \\
\hline Total & 62 & 100 \\
\hline
\end{tabular}




\section{2 - Informações Clínicas}

A partir das queixas clínicas apresentadas pelos sujeitos que buscaram atendimento no pronto socorro, a Tabela 2 mostra que 20 dos entrevistados $(32,2 \%)$ declararam e foram classificados, após a consulta médica, com Hipótese Diagnóstica de Cefaléia, o que está em destaque. Ainda em queixa que os levou ao pronto socorro, foram agrupadas em ordem de sistemas: relacionadas ao aparelho digestivo (dor abdominal a esclarecer, epigastralgia, dispepsia, gastro enterocolite aguda); relacionadas ao aparelho locomotor (cervicalgia, lombalgia, ciatalgia, dorsalgia, lombociatalgia e mialgia crônica); relacionadas ao aparelho geniturinário (cólica nefrética, disúria, infecção do trato urinário, cólica menstrual); relacionadas ao aparelho circulatório (hipertensão arterial sistêmica, precordialgia, edema de membros inferiores); relacionadas ao aparelho respiratório (amigdalite, gripe, infecção viral aguda, tosse não específica, dispnéia); outras doenças (reação alérgica, politraumatismo, hipoglicemia, febre a esclarecer).

Com relação à pressão arterial, seguindo a classificação do III Consenso Brasileiro de Hipertensão Arterial (1998), pode-se considerar hipertensão quando o paciente apresentar Pressão Arterial Sistólica (PAS) maior ou igual a $140 \mathrm{mmHg}$ e Pressão Arterial Diastólica (PAD) maior ou igual a $90 \mathrm{mmHg}$. Para tanto foi verificado que 48 individuos $(76,8 \%)$ apresentaram PAS entre 100 e $139 \mathrm{mmHg}$ e PAD entre 60 e $89 \mathrm{mmHg}$, no

momento da consulta e 14 pessoas $(23,2 \%)$ apresentaram-se em 
hipertensão leve, moderada ou severa. Pulso não foi sinal vital percebido como fora dos limites de normalidade e temperatura só apareceu como febre em um paciente relacionado à infecção viral aguda (gripe).

Para o uso de medicações, também por se tratar de uma questão aberta, foram agrupados em nenhuma medicação, uma medicação, 2 ou mais medicações, conforme se observa na Tabela 2 .

Para o número de consultas em pronto socorro nos últimos 12 meses, $42(67,7 \%)$ responderam que não passaram por nenhuma consulta, $10(16,1 \%)$ passaram entre 1 a 3 consultas, quatro $(6,5 \%)$ passaram por mais de 3 consultas e seis $(9,7 \%)$ não informaram.

Quando se analisa o item "outras doenças", percebe que, mesmo se tratando de uma resposta aberta, é possível fazer alguns agrupamentos, ou seja, 52 indivíduos (83,9\%) afirmam não apresentar nenhuma, outros $6(9,6 \%)$ alegam queixa de algum sintoma relacionado à dor (angina, enxaqueca, lombalgia, mialgia); e outros 4 indivíduos $(6,4 \%)$ referem outras doenças ou sintomas (asma, rinite, sinusite, bronquite, hipoglicemia, prolapso cardíaco).

Quando questionados sobre ter um diagnóstico de depressão em algum momento de suas vidas, $8(12,9 \%)$ responderam que sim, sendo 7 mulheres e 1 homem. Quando questionados os oito indivíduos da pesquisa, se já trataram, 6 responderam que sim, 2 responderam que não.

No contexto de sono e repouso, também classificou-se por períodos, conforme apresentado na Tabela 2. Entretanto, é interessante observar 
que quando se compara o período de sono relatado com a afirmação dos entrevistados frente a insônia, esta está presente em 26 indivíduos (41,9\%), nos quais temos que a insônia é inicial para 16 indivíduos $(25,8 \%)$, é intermediária para $7(11,3 \%)$ e final para $3(4,8 \%)$.

Quanto à atividade física, 29 pessoas $(46,8 \%)$ não praticam nenhuma e $20(32,3 \%)$ referem praticar caminhada. As outras 13 $(20,8 \%)$ deram respostas entre corrida, ginástica, jogos, natação e musculação. Do total que pratica atividade física, 18 (29\%) realizam sozinhos e $15(24,2 \%)$ realizam com companhia.

Alimentação foi outro fator muito disperso o que impossibilitou agrupar para análise.

Fumo, álcool, drogas ou outras drogas ilícitas são apresentados também na Tabela 2, sendo importante observar que o item "jogos" não apareceu em nenhuma resposta. Acredita-se que isso se deu em virtude dos bingos e casas de jogos terem sido fechadas por ordem judicial nos meses que antecederam a coleta. O item "substância ilícita", declarado por um dos entrevistados é a cocaína.

O fumo, quando afirmativo, era presente diariamente, enquanto que o álcool, quando afirmativo, era presente em grande parte como "recreacional", nos fins-de-semana. Pareceu nas entrevistas que álcool socialmente não é visto como um problema, algo natural na cultura brasileira, tendo em vista que $45,2 \%$ afirmam fazer uso.

Questionados sobre procura por serviço de psicologia ou psiquiatria, $16(25,8 \%)$ responderam que sim e, quando perguntado o motivo, as 
respostas foram muito variadas (estresse pré-vestibular, dificuldade para engravidar, namorado a trocou pela irmã, orientação familiar pelos filhos adolescentes, orientação vocacional, taquicardia, ansiedade, insônia, desmotivação profissional, desemprego, estresse no trabalho, morte da mãe, dificuldade de concentração nos estudos, e algumas recusas em falar também, mas alegando que foi útil).

\section{3 - Contextualização Psicossocial}

Outro item muito abrangente referia-se a evento marcante nos últimos 12 meses. Cabe ressaltar que 24 indivíduos $(38,7 \%)$ negaram haver eventos marcantes nesse período e $7(11,3 \%)$ referem mudança de emprego como evento. Não foi possível agrupar as respostas, mas destacaram-se: desemprego do marido, desemprego próprio, estresse no estágio ou no trabalho, risco de demissão, perda do emprego anterior, mudança de residência, mudança de cidade, morte do pai, morte da prima, termino de namoro, termino de noivado, separação, cirurgia própria ou de familiar, vestibular, decepção com relacionamento, dificuldades com pretendentes, brigas, distanciamento do pai, e houve quem se recusasse a falar também.

Quanto a problemas de relacionamento, observa-se na Tabela 3, em ordem de relevância, 38 (61,3\%) responderam não ter, $11(17,7 \%)$ responderam ter com colegas, $8(12,9 \%)$ com pai e/ou mãe, $3(4,8 \%)$ com amigos e 2 (3,2\%) com cônjuge. 
Problemas com separação ou divórcio, 57 (91,9\%) negaram. Na questão aberta sobre outros possíveis problemas de relacionamento, 47 $(75,8 \%)$ negam tal situação, 8 pessoas $(12,9 \%)$ alegam problemas relacionados ao trabalho (estresse com colegas, com chefia, trabalho estressante) e $5(8,1 \%)$ relacionados a namorado(a).

Os problemas de ordem familiar que se observam na Tabela 3 mostram que ainda que a maioria $(56,5 \%)$ alegue não ter problemas de ordem familiar, uma considerável parcela $(17,7 \%)$ afirma problemas de ordem familiar relacionado a álcool e drogas. Comparando com a Tabela 2, em hábitos, observa-se que 28 indivíduos $(45,2 \%)$ afirmaram fazer uso de bebida alcoólica, mesmo que considerem isso um ato social.

Para problemas de ordem econômica, 9 (14,5\%) referem que sim e para aposentadoria $61(98,4 \%)$ assinalam não. Cabe ressaltar que um é aposentado, refere problema com aposentadoria, mas não foi classificado na Tabela 1 como aposentado, pois continua a trabalhar, não se definindo como aposentado em sua ocupação.

Na Tabela 3 também observa-se a distribuição do grau de satisfação com a moradia em que vivem os entrevistados, encontram-se $48,4 \%$ tranqüilos em relação à moradia. Quanto a mudança de residência nos últimos 12 meses, $10(16,1 \%)$ responderam que sim e $52(83,9 \%)$ responderam que não. 
Tabela 2 - Distribuição das informações clínicas dos pacientes atendidos no

Pronto Socorro durante o plantão noturno. Campinas, 2008.

\begin{tabular}{|c|c|c|}
\hline Variável $(n=62)$ & Freqüência & $\%$ \\
\hline \multicolumn{3}{|l|}{ Tipo de queixa clínica } \\
\hline Cefaléia & 20 & 32,2 \\
\hline Relacionadas ao Aparelho Digestório & 12 & 19,4 \\
\hline Relacionadas ao Aparelho Locomotor & 7 & 11,3 \\
\hline Relacionadas ao Aparelho Geniturinário & 6 & 9,6 \\
\hline Relacionadas ao Aparelho Circulatório & 5 & 8,1 \\
\hline Relacionadas ao Aparelho Respiratório & 7 & 11,3 \\
\hline Outras & 5 & 8,1 \\
\hline \multicolumn{3}{|l|}{ Número de medicações em uso } \\
\hline 0 & 37 & 59,9 \\
\hline 1 & 19 & 30,4 \\
\hline 2 ou mais & 5 & 8,1 \\
\hline Não informado & 1 & 1,6 \\
\hline \multicolumn{3}{|l|}{ Diabetes } \\
\hline Sim & 1 & 1,6 \\
\hline Não & 61 & 98,4 \\
\hline \multicolumn{3}{|l|}{ Hipertensão Arterial Sistêmica } \\
\hline Sim & 9 & 14,5 \\
\hline Não & 53 & 85,5 \\
\hline \multicolumn{3}{|l|}{ Obesidade } \\
\hline Sim & 8 & 12,9 \\
\hline Não & 54 & 87,1 \\
\hline \multicolumn{3}{|l|}{ Diagnóstico anterior de depressão } \\
\hline Sim & 8 & 12,9 \\
\hline Não & 54 & 87,1 \\
\hline \multirow{2}{*}{\multicolumn{3}{|c|}{ Tempo de sono diário }} \\
\hline & & 9,7 \\
\hline 6 a 8 horas & 48 & 77,4 \\
\hline$>8$ horas & 8 & 12,9 \\
\hline \multicolumn{3}{|l|}{ Insônia declarada } \\
\hline Sim & 26 & 41,9 \\
\hline Não & 36 & 58,1 \\
\hline \multicolumn{3}{|l|}{ Prática de atividade física } \\
\hline Sim & 33 & 53,2 \\
\hline Não & 29 & 46,8 \\
\hline \multicolumn{3}{|l|}{ Uso de tabaco } \\
\hline Sim & 13 & 21,0 \\
\hline Não & 49 & 79,0 \\
\hline \multicolumn{3}{|l|}{ Uso de álcool } \\
\hline Sim & 28 & 45,2 \\
\hline Não & 34 & 54,8 \\
\hline \multicolumn{3}{|l|}{ Uso de substâncias ilícitas } \\
\hline Sim & 1 & 1,6 \\
\hline Não & 61 & 98,4 \\
\hline Total & 62 & 100,0 \\
\hline
\end{tabular}

Com relação aos recursos da comunidade encontrou-se que a grande maioria $(82,3 \%)$ usa três recursos ou mais. Vale ressaltar que as respostas possíveis e cumulativas eram: 1) Supermercado, 2) Igreja, 
3) Padaria, 4) Farmácia, 5) Posto de saúde, 6) Praça, 7) Delegacia, 8) Escola.

Tabela 3 - Distribuição das informações referentes à contextualização psicossocial dos pacientes atendidos no Pronto Socorro durante o plantão noturno. Campinas, 2008.

\begin{tabular}{lrr}
\hline \multicolumn{1}{c}{ Variável (n=62) } & Freqüência & \% \\
\hline Problemas de relacionamento & 38 & \\
Não tem & 8 & 61,3 \\
Pai e/ou mãe & 2 & 12,9 \\
Cônjuges & 3 & 3,2 \\
Amigos & 11 & 4,8 \\
Colegas & & 17,7 \\
Problemas familiares & 35 & \\
Não tem & 10 & 56,5 \\
Doença & 3 & 16,1 \\
Óbito & 3 & 4,8 \\
Violência & 11 & 4,8 \\
Álcool / Drogas & & 17,7 \\
Satisfação com moradia & 1 & \\
Nada & 3 & 1,6 \\
Pouco & 28 & 4,8 \\
Médio & 21 & 45,2 \\
Bastante & 9 & 33,9 \\
Muito & $\mathbf{6 2}$ & 14,5 \\
\hline Total & & $\mathbf{1 0 0 , 0}$ \\
\hline
\end{tabular}

O mesmo procedimento aplicado a lazer mostrou que a grande maioria $(93,5 \%)$ usa três ou mais atividades de lazer, sendo as possíveis respostas cumulativas: 1)TV, 2) Vídeo/DVD, 3) Música, 4) Rádio, 5) Cinema, 6) Baile, 7) Praça, 8) Shopping, 9) Centro.

Importante ressaltar que algumas respostas para "baile", quando perguntados aos mais jovens era respondido também com o termo "Balada". Outro item que não constava no questionário, mas que foi dito diversas vezes, foi o uso de internet como canal de lazer.

No tocante à companhia para essas atividades de lazer, $24(38,7 \%)$ realizam sozinhos e $38(61,3 \%)$ realizam acompanhados. A maioria 
$(93,5 \%)$ não participa de nenhuma ocupação voluntária e somente 4 $(6,5 \%)$ afirmam realizar algo desta natureza.

\section{4 - Presença de depressão entre os entrevistados}

A Tabela 4 mostra os resultados da investigação sobre a presença ou ausência de depressão entre os 62 entrevistados, no período de 16 de novembro a 17 de dezembro de 2007, no Pronto Socorro durante o período noturno. Observa-se que $21 \%$ apresentam-se com depressão (sendo $8,1 \%$ moderada e $12,9 \%$ leve).

O ponto de corte utilizado para a classificação dos escores foi de até 15 sem depressão, de 16 a 20 para depressão leve, de 21 a 29 depressão moderada e acima de 30 depressão grave, utilizando-se o Inventário de Depressão de Beck como instrumento de registro das informações.

Analisando as respostas de cada uma das 21 questões do Inventário de Beck, em sua ordem, é importante destacar as respostas mais freqüentes.

O sentimento de tristeza foi assinalado por 24 pacientes $(38,7 \%)$, sendo que dois deles $(3,2 \%)$ sentem-se tão tristes que não conseguem suportar.

Quanto ao futuro $44(71,0 \%)$ afirmam ter esperanças e $18(29,0 \%)$ afirmam estar desanimadas, ou não ter esperanças ou acham que as coisas não vão melhorar. 
Tabela 4 - Distribuição da freqüência de depressão entre usuários atendidos no Pronto Socorro, durante o plantão noturno. Campinas, 2008.

\begin{tabular}{crrrrrr}
\hline Depressão & \multicolumn{2}{c}{ Masculino } & \multicolumn{2}{c}{ Feminino } & \multicolumn{2}{c}{ Total } \\
& $\mathbf{f}$ & $\mathbf{\%}$ & $\mathbf{f}$ & $\mathbf{\%}$ & $\mathbf{F}$ & $\mathbf{\%}$ \\
\hline Sem depressão & 12 & 19,2 & 37 & 59,8 & 49 & 79,0 \\
Disforia/Leve & 1 & 1,6 & 7 & 11,3 & 8 & 12,9 \\
Moderada & 2 & 3,2 & 3 & 4,9 & 5 & 8,1 \\
Grave & 0 & 0,0 & 0 & 0,0 & 0 & 0,0 \\
Total & $\mathbf{1 5}$ & $\mathbf{2 4 , 2}$ & $\mathbf{4 7}$ & $\mathbf{7 5 , 8}$ & $\mathbf{6 2}$ & $\mathbf{1 0 0 , 0}$ \\
\hline
\end{tabular}

O sentimento de tristeza foi assinalado por 24 pacientes $(38,7 \%)$, sendo que dois deles $(3,2 \%)$ sentem-se tão tristes que não conseguem suportar.

Quanto ao futuro $44(71,0 \%)$ afirmam ter esperanças e $18(29,0 \%)$ afirmam estar desanimadas, ou não ter esperanças ou acham que as coisas não vão melhorar.

Das 62 pessoas entrevistadas, $50(80,6 \%)$ disseram que não se sentem um fracasso, ao passo que $11(17,7 \%)$ alegam que fracassaram mais do que uma pessoa comum e um $(1,6 \%)$ diz que tudo o que vê em sua vida é um monte de fracassos, mas nenhum entrevistado se considerou um completo fracasso.

Prazer nas atividades que realiza aparece para 30 indivíduos $(48,4 \%)$, ao passo que $30(48,4 \%)$ não sentem prazer ao realizar as coisas como antes e dois $(3,6 \%)$ sentem-se insatisfeitos e aborrecidos com tudo. 
Quanto a sentimentos de culpa, $41(66,1 \%)$ não se sentem culpados, $20(32,3 \%)$ se sentem culpados grande parte do tempo e um $(1,6 \%)$ se sente sempre culpado. Observa-se que $37(59,7 \%)$ não acha que está sendo punido, $19(30,6 \%)$ acha que pode ser punido e $6(9,7 \%)$ acha que está sendo punido.

O sentimento de decepção é negado em $36(58,1 \%)$ indivíduos, 21 $(33,9 \%)$ aparecem como decepcionados consigo mesmos, $4(6,5 \%)$ referem se odiar e somente um (1,6\%) admite estar aborrecido consigo.

Dos 62 entrevistados, $29(46,8 \%)$ declaram-se críticos em relação a si por suas fraquezas e erros e somente um $(1,6 \%)$ se culpa sempre por suas faltas.

A ideação suicida está presente em 6 pessoas $(9,7 \%)$, mas não as executariam, ao passo que uma pessoa $(1,6 \%)$ refere que gostaria de se matar. Dezenove $(30,6 \%)$ choram mais do que costumavam e $6(9,7 \%)$ se dizem incapazes de chorar mesmo que queiram; $11(17,7 \%)$ referem não se irritar com as coisas mais do que se irritavam, $2(3,2 \%)$ se sentem irritados o tempo todo e $33(53,2 \%)$ se aborrecem ou se irritam mais facilmente do que de costume.

Um terço dos sujeitos refere menos interesse pelas outras pessoas, e dois $(3,2 \%)$ referem ter perdido a maior parte do interesse pelos outros.

Para tomada de decisão, $42(67,7 \%)$ mantêm-se tão bem quanto antes, $15(24,2 \%)$ adiam as tomadas de decisões e $5(8,1 \%)$ referem mais dificuldade em tomar decisões do que antes. 
Um entrevistado se acha feio, $10(16,1 \%)$ consideram que houve mudanças em sua aparência permanentemente e que, portanto não se sentem mais atraentes, $14(22,6 \%)$ sentem-se preocupados por parecerem mais velhos ou sem atrativos e $37(59,7 \%)$ não se sentem preocupados com esse fato.

Quanto à disposição para atividades e trabalho, $42(67,7 \%)$ não apresentam queixa, $17(27,4 \%)$ admitem que precisam de um esforço extra para conseguir fazer algo e três $(4,8 \%)$ precisam de muito esforço para fazer alguma coisa.

No aspecto sono, $28(45,2 \%)$ indicam não apresentarem alteração, ao passo que $34(54,8 \%)$ relatam problemas, sendo $28(45,2 \%)$ que não dormem tão bem como costumavam, $3(4,8 \%)$ que acordam mais cedo tendo dificuldades para voltar a dormir e $3(4,8 \%)$ que acordam várias horas mais cedo e não conseguem voltar a dormir.

O sintoma cansaço é citado pela grande maioria das pessoas, sendo que $40(64,5 \%)$ ficam mais cansadas com mais facilidade do que ficava e uma delas sente-se cansada ao fazer qualquer coisa.

Quando perguntados sobre apetite, $40(64,5 \%)$ negam alterações e $20(32,2 \%)$ alegam que o apetite não é tão bom quanto costumava ser, $54(87,1 \%)$ referem não ter perdido peso, dos $8(12,9 \%)$ que perderam peso, a maioria estava tentando perder.

Preocupação com problemas físicos (dores, indisposição de estômago e prisão de ventre) é declarada pela maioria dos entrevistados $(51,6 \%)$, além de $5(8,0 \%)$ que estão tão preocupados que é difícil pensar 
em outra coisa ou não conseguem pensar em outra coisa. No final, menos da metade $25(40,3 \%)$ são os que não apresentam mudança na preocupação com a saúde.

Com relação ao sexo, $42(67,7 \%)$ não referem nenhuma mudança, ao passo que $17(27,4 \%)$ citam interesse diminuído e três $(4,8 \%)$ referem muito menos interesse ou perda de interesse.

O que chamou a atenção nas respostas do Inventário de Beck foram as questões $4,8,11,16,17$ e 20 apresentando alterações significativas com respostas para a maioria ou muito próximo da maioria respectivamente em prazer, autocrítica, irritabilidade, sono, cansaço e preocupação com saúde.

\section{5 - Correlação entre depressão, dados sociodemográficos e clínicos}

Como mostra a Tabela 5, o teste de Fisher foi significativo para as variáveis: hábito de fumar $(p=0,021)$, insônia $(p=0,005)$ e problemas econômicos $(p<0,000)$.

Assim, conclui-se que fumantes e não fumantes distribuíram-se diferentemente entre os indivíduos que apresentavam depressão. O mesmo ocorre para aqueles que declararam insônia e problemas econômicos. Houve maior número de deprimidos entre os fumantes quando comparado aos não fumantes. Da mesma forma, entre os indivíduos que apresentavam insônia havia mais deprimidos do que entre 
aqueles que não apresentavam insônia. No que se refere a ter problemas econômicos, entre os sujeitos que possuíam essa característica havia mais deprimidos do que entre os que negaram problemas econômicos.

As demais categorias investigadas (hábito de beber, sexo, atividade física e diagnóstico anterior de depressão) não apresentaram diferença estatisticamente significativa entre os pacientes deprimidos.

O teste de Fisher foi considerado e utilizado conforme Berquó, Gotlieb \& Souza (2006), tendo em vista a distribuição das amostras, 2x2, o que não permitiam uma distribuição normal para a realização do teste de hipóteses.

Tabela 5 - Distribuição da freqüência de depressão segundo as variáveis independentes e significância do Teste de Fisher em pacientes atendidos no Pronto Socorro durante o plantão noturno. Campinas, 2008.

\begin{tabular}{|c|c|c|c|c|}
\hline \multirow{2}{*}{ Categoria } & \multicolumn{2}{|c|}{ Depressão } & \multirow{2}{*}{ Total } & \multirow{2}{*}{$\begin{array}{c}\text { Teste de } \\
\text { Fisher }(p)\end{array}$} \\
\hline & Freqüência & $\%$ & & \\
\hline \multicolumn{5}{|c|}{ Hábito de Fumar } \\
\hline Sim & 6 & 46,2 & 13 & $* 0,021$ \\
\hline Não & 7 & 53,8 & 49 & $* 0,021$ \\
\hline \multicolumn{5}{|c|}{ Hábito de Beber } \\
\hline Sim & 7 & 53,8 & 28 & 0,345 \\
\hline Não & 6 & 46,2 & 34 & 0,345 \\
\hline \multicolumn{5}{|l|}{ Insônia } \\
\hline Sim & 10 & 76,9 & 26 & $* 0,005$ \\
\hline Não & 3 & 23,1 & 36 & $* 0,005$ \\
\hline \multicolumn{5}{|l|}{ Obesidade } \\
\hline Sim & 2 & 15,4 & 8 & 0,536 \\
\hline Não & 11 & 84,6 & 54 & 0,536 \\
\hline \multicolumn{5}{|l|}{ Hipertensão } \\
\hline Sim & 1 & 7,7 & 9 & 0,390 \\
\hline Não & 12 & 92,3 & 53 & 0,390 \\
\hline \multicolumn{5}{|l|}{ Sexo } \\
\hline Feminino & 9 & 69,2 & 47 & 0,385 \\
\hline Masculino & 4 & 30,8 & 15 & 0,385 \\
\hline \multicolumn{5}{|c|}{ Atividade física } \\
\hline Sim & 5 & 38,5 & 26 & 0,516 \\
\hline Não & 8 & 61,5 & 36 & 0,516 \\
\hline \multicolumn{5}{|c|}{ Depressão Anterior } \\
\hline Sim & 3 & 23,1 & 8 & 0,214 \\
\hline Não & 10 & 76,9 & 54 & 0,214 \\
\hline \multicolumn{5}{|c|}{ Problemas Econômicos } \\
\hline Sim & 7 & 53,8 & 9 & $*<0,000$ \\
\hline Não & 6 & 46,2 & 53 & $*<0,000$ \\
\hline
\end{tabular}

Significativo ao nível de significância $a=0,05$. 


\section{6 - Discussão}

Esta pesquisa trabalhou com uma amostra não diagnosticada, evidenciando que $21 \%$ da amostra apresentava depressão leve e/ou moderada, o que a priori pode parecer uma taxa alta de deprimidos, quando comparado com dados de Lafer et al (2000), quando cita números dos Estados Unidos de 1,5 a 2,6\% para depressão maior e 2,1 a 4,2\% para depressão leve, bem como números brasileiros de 1,9\% de deprimidos em São Paulo, 2,8\% em Brasília e 10,2 \% em Porto Alegre. E Breslin (1995) que apresenta uma taxa de $6 \%$ de depressão para a população em geral. Bem como demostrou-se neste estudo uma prevalência de $12 \%$ de depressão anterior, o que não foge à discussão destes autores.

Entretanto, por se tratar de uma amostra que já apresenta uma situação clínica, ou seja, pacientes que por algum motivo, seja orgânico, psíquico, ou mesmo social, somatizado ou não, sentem-se na necessidade de buscar uma ajuda num serviço de saúde, por isso já é possível dizer que essa amostra não é insuspeita, assim concorda-se com Botega et al (1995), Lafer et al (2000), Mata e Moreira Filho (2003), Costa e Chaves (2004), Maj e Sartorius (2005), Teng, Humes e Demétrio (2005), Carvalho et al (2007), Amaral et al (2007) que para todos estes estudos, há uma relação direta entre doenças clínicas e sintomas depressivos, o que remete a uma atenção maior para todos os pacientes que procuram algum tipo de serviço de saúde. 
Chama a atenção o fato destes trabalhos acharem um aumento da presença de sintomas depressivos em seus pacientes portadores de alguma doença clínica de base e assim reforçam que para aquela patologia, é necessário estar atento aos sintomas depressivos e procurar atender o cliente que os vivencia, o que facilita a adesão ao tratamento, evitando perdas sociais, sofrimentos, agravamento com risco de suicídio. Se todas as pesquisas citadas, mostram que para cada patologia há aumento na taxa de depressão, então conclui-se para o presente estudo, que qualquer patologia pode por si só aumentar a prevalência de sintomas depressivos, e vice versa, como afirma Maj e Sartorius (2005).

No serviço de emergência, tendo em vista o que Rodríguez (2000) afirma sobre o fluxo de atendimentos, que por passar a atender uma demanda que não compete a ele, sobrecarregando-o, assim espera-se que apareça todo tipo de situação clínica em um Pronto Socorro, Pronto Atendimento ou Emergência, cabendo à equipe de saúde, ter consciência que a porcentagem de deprimidos será aumentada, seja porque o paciente apresenta-se deprimido como base, seja porque a doença ou problema que o acomete virá acompanhado de forte carga emocional que o disporá a depressão mais facilmente, estando atento a esses números bem como sua resolutividade.

Vale observar que, segundo artigo de revisão de Moreira-Almeida, Lotufo Neto e Koenig (2006), níveis de envolvimento religioso estão associados positivamente a indicadores de bem estar psicológico (satisfação com a vida, felicidade, afeto positivo e moral mais elevado) e a 
menos casos de depressão, pensamentos e comportamentos suicidas, uso/abuso de álcool/drogas. Habitualmente, o impacto positivo do envolvimento religioso na saúde mental é mais intenso entre pessoas sob estresse, existindo, portanto, evidências suficientes para se afirmar que o envolvimento religioso habitualmente está associado à melhor saúde mental. Entretanto, o que na prática se observa, segundo declaração dos sujeitos deste estudo, é que a maioria $(58,1 \%)$ se declara não praticante de atividade religiosa. Entao, se a prática religiosa protege, neste caso pode-se dizer que não, pois como prática ela é insignificante.

Quatorze pessoas $(23,2 \%)$ apresentaram-se em hipertensão leve, moderada ou severa. Para Maj e Sartorius (2005) e Teng, Humes e Demetrio (2005) pacientes deprimidos têm risco significativamente maior de desenvolver doença cardíaca isquêmica e/ou hipertensão, e o inverso também é verdadeiro. Porém, somente 35\% dos pacientes deprimidos são adequadamente tratados, sendo subdiagnosticados, ou tratados de forma inadequada, comprometendo a adesão ao tratamento.

Foi possível perceber nos resultados que não havia uma relação direta entre aumento de depressão neste estudo e aumento de doenças como obesidade, diabetes ou Infarto. Talvez pudéssemos supor que a amostra composta por uma parcela relativamente jovem, não estivesse tão ligada a doenças crônico-degenerativas, relacionadas talvez a maturidade.

Outro item que chamou a atenção é a relação de uso de bebidas alcoólicas por boa parte dos entrevistados e queixas de problemas 
familiares com álcool e drogas, o que necessitaria de estudo mais detalhado para hipóteses dessa relação, mas acredita-se que álcool seja realmente um fator não encarado pela sociedade como droga, tendo em vista a publicidade relacionada.

Corrobora-se positivamente os dados desta pesquisa, quando comparados mulheres e homens deprimidos, acometendo duas vezes mulheres que homens como citam Lafer et al (2000), Silva, Furegato e Costa (2003), Perez et al (2005), Nievas, Furegato e Santos (2006) e Justo e Calil (2006). Da mesma forma, observa-se a idade dos entrevistados, já que indivíduos jovens relatam mais frequentemente histórias de depressão, sendo mais susceptíveis adultos entre 25 e 44 anos, como afirma Bee (1997), sendo fatores ambientais, urbanização e mudanças na estrutura familiar como predisponentes.

Neste ponto pensa-se nos dados que o teste de Fisher mostrou onde "problemas econômicos" $(P<0,000)$ aparecem negativamente, o que chama a atenção, pois se trata de uma amostra trabalhadora, onde ninguém alegou desemprego. Nas questões abertas, por diversas vezes havia relato de estresse no trabalho, desentendimento com colegas de trabalho, cobranças de chefia, entre outros. Neste aspecto Willians, Fann e Strasser (1999) trazem dados interessantes quando relacionam a depressão com impacto econômico, determinando que a depressão apresenta maior custo/benefício médico de todos os comportamentos das condições de saúde. O que num estudo mais profundo, numa amostra maior, ou numa análise desta pesquisa que permitisse esse grau de 
compreensão, pudesse perceber também estes custos sociais para a parcela trabalhadora caracterizada nesta pesquisa, economicamente ativa e com bom nível educacional. É necessário perceber as necessidades do trabalhador e intervir. Antes que a depressão, para ele, torne-se um motivo de perdas severas até mesmo irreparáveis.

Cefaléia foi a queixa que apareceu com forte freqüência $(32,2 \%)$ entre os entrevistados. Seria esperada até maior prevalência de depressão em pessoas que apresentam cefaléia crônica, como afirma Matta e Moreira Filho (2003). Talvez haja relação de estresse no trabalho que se manifesta como cefaléia? Uma análise mais profunda e apurada seria necessária para tal afirmação.

Fumo aparece também como fator negativo $(P=0,021)$ para os deprimidos e isso corrobora positivamente dados de Rondina, Gorayeb e Botelho (2003) e (2007) e Malbergier e Oliveira (2005), que afirmam uma forte associação entre tabagismo e transtornos depressivos, sendo que a cessação do tabagismo é fator de risco para a manutenção do quadro clínico ou o desenvolvimento de novos surtos depressivos, bem como a um maior risco de crises de pânico. Portanto, retormando Kapczinski et al (2001), se são nas emergências dos hospitais gerais que as descompensações psiquiátricas vão aparecer, por não mais existirem os manicômios, e o paciente estar em convívio social, cabe à equipe atender a esses casos, sendo puramente psiquiátricos, clínicos ou ambos, e apresentar um grau de resolutividade e dignidade para a pessoa que sofre. 
A insônia também foi fator que o teste de Fisher mostra relevância negativa ( $P=0,005)$, e neste sintoma Luchesi et al (2005) afirma que insônia e transtornos psiquiátricos estão intimamente associados, com mais prevalência para dificuldade para iniciar e manter o sono, o que também foi relatado como insônia inicial neste pesquisa. Para Chellappa e Araújo (2006), a insônia é uma característica marcante do transtorno depressivo, podendo ocorrer nos primeiros estágios da depressão, antecipá-la ou ser um sintoma residual, o que necessitaria de uma atenção maior, tendo em vista sua facilidade de verbalização pelo paciente.

Vale ressaltar que o constructo do questionário de identificação dos sujeitos desta pesquisa, levou em consideração três aspectos, a saber: identificação do sujeito, informações clínicas e contextualização social, sendo que em dois aspectos o teste de Fisher apresentou relevância negativa, o que mostra que este questionário foi útil para relacionar os sintomas depressivos, dados pelo Inventário de Beck, aos condicionantes clínicos e contextuais, a que este estudo se propôs. Ainda mostra que é possível e necessário ao enfermeiro que atua em unidade de emergência, seja privado ou público, atuar frente a essas questões na busca pela melhora da qualidade do serviço e quebra de dogmas socialmente enraizados sobre aspectos psiquiátricos de quem sofre, tendo em vista que trabalhos da OPAS e OMS (2001) demonstram que a depressão deverá mostrar tendência ascendente nos próximos 20 anos. 


\section{VI - CONCLUSOES}

A amostra de freqüentadores do Pronto Socorro do Hospital Irmãos Penteado representa uma parcela da população que pede atenção da saúde fora do fluxo de consultas, cirurgias e outros procedimentos médicos na rede de atenção a saúde pública.

Como citado, este serviço atende somente a pacientes que dispõem de convênio de saúde que, ou é oferecido pela empresa onde trabalha, ou é pago com seus próprios recursos, proveniente de seu trabalho. Assim, é importante destacar os dados que chamaram a atenção:

- Maioria mulheres.

- Maioria branca.

- Maioria faixa etária entre 18 e 30 anos.

- Bom nível educacional e nenhum analfabeto.

- Maioria de trabalhadores de comercio e administração.

- Maioria vive sem companheiro (a).

- Queixa mais comum de cefaléia e problemas aparelho digestório.

- Mais de um décimo com diagnostico anterior de depressão.

- Boa parte apresenta queixa de insônia inicial.

- Maioria pratica atividade física.

- Quase metade faz uso de álcool, destaque para quase um quinto afirmar ter problemas com álcool ou drogas na família. 
- Como evento marcante, boa parte cita situações relacionadas ao trabalho, a emprego ou desemprego, estresse e cobrança, bem como problemas de relacionamento com colegas de trabalho tendo certo destaque.

- Há uma boa satisfação com moradia.

- Grande maioria usa de vários recursos da comunidade e também grande maioria usa de vários canais de lazer.

- Para depressão houve um percentual significativo de disforia (depressão leve) e depressão moderada se comparado à literatura. Com mulheres aparecendo mais que o dobro de homens. Sendo que dos deprimidos o fumo, a insônia e problemas econômicos apareceram como fatores em destaque.

- Para o Inventário de Beck foram itens críticos negativamente: prazer, autocrítica, irritabilidade, sono, cansaço e preocupação com a saúde.

O estudo mostrou que os sintomas depressivos estavam aumentados para a amostra estudada, quando comparados a amostras não diagnosticadas e insuspeitas, entretanto a amostra em questão é sim não diagnosticada, mas não insuspeita, estando em acordo com os dados de pesquisa de depressão associadas à outras doenças clinicas em hospital geral. Vale lembrar que qualquer patologia pode por si só 
aumenta a prevalência de sintomas depressivos, e o contrário também é verdadeiro.

Correlacionaram negativamente neste estudo da depressão o fumo, problemas econômicos e insônia, bem como estresse no trabalho ou fatores relacionados a este.

Permitiu também concluir que o Inventário de Beck é de fácil aplicação e compreensão principalmente para uma amostra com bom nível educacional, o que facilita o levantamento das necessidades do cliente para o planejamento das ações de enfermagem, ganhando tempo, tendo em vista o local da pesquisa ter sido um Pronto Socorro em instituição privada, com fluxo e dinâmica característicos.

Em vistas das analises e dos achados, sugere-se outros estudos mais detalhados e com maior número de sujeitos a fim de elucidar esse "estresse no trabalho" ou outros fatores relacionados a este, bem como estudos que favoreçam o cuidado de enfermagem, tendo em vista que o serviço privado de saúde não está tão atento à resolutividade do problema do cliente quando se trata de saúde mental. Estes estudos permitiriam mostrar com mais detalhes o impacto econômico in loco que a depressão tem no social, despertando o interesse das grandes empresas de saúde para com a temática e incentivando a melhora da qualidade da saúde mental para o cidadão trabalhador ou não. 


\section{VII - BIBLIOGRAFIA}

ABRAMSON, L.Y.; SELIGMAN, M.E.P.; TEASDALE, J. Learned helpness in humans: critique and reformulation. Journal of Abnormal Psychology, 87, 49-74, 1977.

ALMEIDA, M.C.P.; ROCHA, J.S.Y. O saber de enfermagem e sua dimensão prática. São Paulo: Cortez, 1986.

AMARAL, G.F.; JARDIM, P.C.B.V.; BRASIL, M.A.A.; SOUZA, A.L.L.; FREITAS, H.F.; TANIGUCHI, L.M.; MELO, A.F.B.de; RIBEIRO, C.N. prevalência de transtorno depressivo maior em centro de referência no tratamento de hipertensão arterial. Rev Psiquiatr RS. 2007; 29(2):161168.

ARROYO, Qualidade de serviços de assistência à saúde: o tempo de atendimento da consulta médica. 2007, 129p. Tese (Doutorado), Faculdade de Economia, Administração e Contabilidade, Universidade de São Paulo.

BECK, A.T.; WARD, C.H.; MENDELSON, M.; MOCK, J.; ERBAUGH, J. An inventory for measuring depression. Archives of General Psychiatry. $4: 551-571,1961$.

BECK, J.S. Terapia Cognitiva: teoria e prática. Porto Alegre: Artes Médicas, 1997.

BECK, A.T.; RUSH, A.J.; SHAW, B.F.; EMERY, G. Terapia cognitiva da depressão. Porto Alegre: Artes Médicas, 1997. 
BEE, H. O ciclo vital. Porto Alegre: Artes Médicas, 1997.

BERQUÓ, Elza Salvatori; GOTLIEB, Sabina Léa Davidson; SOUZA, José Maria Pacheco. Bioestatística. 2.ed. São Paulo: EPU, 2006, 352p.

BOTEGA, N.J.; BIO, M.R.; ZOMIGNANI, M.A.; GARCIA JUNIOR, C.; PEREIRA, W.A.B. Transtorno do humor em enfermaria de clínica médica e validação de escala de medida (HAD) de ansiedade e depressão. Rev Saúde Publica. 29(5):355-63, 1995.

BRASIL, Ministério da Saúde. Terminologia básica em saúde. $2^{\mathrm{a}}$ ed. Brasília: Centro de Documentação do Ministério da Saúde, 1985.

BRASIL, Ministério da Saúde. Conselho Nacional de Saúde. Resolução 196/96. Brasília: Centro de Documentação do Ministério da Saúde, 1996.

BURGUESS, A.W. Psychiatric nursing in the hospital and the community. New Jersey: Prentice-Hall, 1981.

BURVILL, P. M. Recent progress in the Epidemiology of Major Depression. Epidemiologic Reviews, 1995.

CALIL, H.M.; PIRES, M.L.N. Aspectos gerais das escalas de avaliação da depressão. Rev Psiq. Clin., Edição Especial, 1999.

CARVALHO, N.S.; RIBEIRO, P.R.; RIBEIRO, M.; NUNES, M.P.T.; CUKIER, A.; STELMACH, R. Asma e doença pulmonar obstrutiva crônica: uma comparação entre variáveis de ansiedade e depressão. J Bras Pneumol. $2007 ; 33(1): 1-6$.

CHELLAPPA, S.L.; ARAÚJO, J.F. Transtorno do sono em pacientes ambulatoriais com depressão. Rev. Psiq. Clín. 33(5); 233-238, 2006. 
CID - 10. Classificação Estatística Internacional das Doenças e Problemas Relacionados à Saúde. São Paulo: EDUSP, 1997.

COSTA, A.L.S.; CHAVES, E.C. Processos de enfrentamento do estresse e sintomas depressivos em pacientes portadores de retocolite ulcerativa idiopática. Rev Esc Enfermagem USP. 2006; 40(4):507-14.

DALGALARRONDO, P. Psicopatologia e semiologia dos transtornos mentais. Porto Alegre: Artes Médicas, 2000.

D'ANDREA, F.F. Transtornos psiquiátricos do adulto. São Paulo: Difel, 1986.

DSM - IV. Manual Diagnóstico e Estatístico de Transtornos Mentais. Porto Alegre: Artes Médicas, 1994.

ELLIS, A. The essence of rational psychotherapy: a comprehensive approach to treatment. Institute for rational living: New York, 1970.

FRAGUAS JUNIOR, R.; ALVES, T.C.T.F. Depressão no hospital geral: Estudo de 136 casos. Rev Assoc Med Bras, 2002; 48(3): 225-30.

FUREGATO, A.R.F. Relações interpessoais terapêuticas na enfermagem. Ribeirão Preto (SP): Scala, 1999.

FUREGATO, A.R.F.; SILVA, E.C.; CAMPOS, M.C.; CASSIANO, R.P.T. Depressão e auto-estima entre acadêmicos de enfermagem. Rev Psiq. Clín. 33(5); 239-244, 2006.

FURLANETO, L.M.; BRASIL, M.A. Diagnosticando e tratando depressão no paciente com doença clínica. Jornal Brasileiro de Psiquiatria, vol.55, n.1, janeiro-março, 2006. 
GOMES, A.L. Emergência: planejamento e organização da unidade. Assistência de enfermagem. São Paulo: Pedagógica e Universitária; 1994. GORENSTEIN, C.; ANDRADE, L. Inventário de Depressão de Beck: propriedades psicométricas da versão em português. Rev Psq. Clin. 25(5) Edição Especial, Set/out, 1998.

HOLLANDER, M.; WOLFE, D.A. Nonparametric statistical methods. $2^{\mathrm{a}}$ edição. New York: John Wiley \& Sons, 1999. 473p.

ITO, L.M.; LOTUFO NETO, F. Teorias cognitivo-comportamentais, interpessoal e construtivista. In: LAFER, B.; ALMEIDA, O.P.; FRÁGUAS JUNIOR, R.; MIGUEL, E.C. Depressão no ciclo da vida. Porto Alegre: Artes Médicas, 2000.

JUSTO, L.P. CALIL, H.M. Depressão - o mesmo acometimento para homens e mulheres? Rev Psiq. Clin. 33(2); 74-79, 2006.

KAPCZINSKI, F.; QUEVEDO, J.; SCHIMITT, R.; CHACHAMOVICH, E. Emergências Psiquiátricas. Porto Alegre: Artmed, 2001.

KENDALL, P.C.; HOLLON, S.D.; BECK, A.T.; HAMMEN, C.I.; INGRAM, R.E. Issues and recommendations regarding use of the Beck Depression Inventory. Cognit Ther Res, 11: 289-99, 1987.

KOIZUMI, M.S. Fundamentos metodológicos da pesquisa em enfermagem. Rev Esc Enf. USP. V. 26, n. especial, out, 1992.

LAFER, B.; ALMEIDA, O.P.; FRÁGUAS JUNIOR, R.; MIGUEL, E.C. Depressão no ciclo da vida. Porto Alegre: Artes Médicas, 2000. 
LUCCHESI, L.M.; PRADELLA-HALLINAN, M.; LUCCHESI, M.; MORAES, W.A.S. O sono em transtornos psiquiátricos. Rev Bras Psiquiatr. 2005; 27 (supl I):27-32.

MACHADO, A.L. Reforma psiquiátrica e mídia: representações sociais na Folha de S. Paulo. Ciência \& Saúde Coletiva. 9(2): 483-491, 2004. MAJ, M.; SARTORIUS, N. Transtornos depressivos. Porto Alegre: Artmed, 2005.

MALBERGIER, A.; OLIVEIRA Jr, H.P. Dependência de tabaco e comorbidade psiquiátrica. Rev. Psiq. Clín. 32(5); 276-282, 2005.

MATTA, A.P.C.; MOREIRA FILHO, P.F. Sintomas depressivos e ansiedade em pacientes com cefaléia do tipo tensional crônica e episódica. Arq Neuropsiquiatr. 2003; 61(4):991-994.

MENDES, I.A.C. Pesquisa em enfermagem: impacto na prática. São Paulo: Editora da Universidade de São Paulo, 1991.

MERENESS, D. Elementos de enfermería psiquiátrica. México: Prensa Médica Mexicana, 1973.

MINZONI, M.A.; ALENCASTRE, M.B.; GOULART, M.C.; PACIENCIA, E.; RODRIGUES, A.R.F.; SILVA, J.N.; CARSWELL, W.A.; SAEKI. T.L. Enfermagem em saúde mental e psiquiatria: a busca de uma posição. Enfermagem em novas dimensões, v.3, n.6, 1977.

MONTGOMERY, S. Confrontando la depressión. Guia del médico. Pfizer international. New York, EUA, 1997. 
NEZU, A.M.; NEZU, C.M.; PERRI, M.G. Problem-solving therapy for depression: theory, research and clinical guidelines. John Wiley \& Sons: New York, 1989.

NIEVAS, A.F.; FUREGATO, A.R.F.; SANTOS, J.L.F. Depressão no climatério: indicadores biopsicossociais. Jornal Brasileiro de Psiquiatria. 55(4): 274-279, 2006.

NIGHTINGALE, F. Notas sobre enfermagem: o que é e o que não é. Trad. Amália Correa de Carvalho. São Paulo: ABEn e Cortez, 1989.

OPAS/ OMS. Programa de Salud Mental, División de Promoción de Salud. Modelo para la capacitación de la enfermera general en al identificación y manejo de los transtornos afectivos. Generalista I, 1999.

OPAS/ OMS. Relatório sobre a saúde no mundo 2001: Saúde Mental: nova concepção, nova esperança. Genebra; 2001.

PEREIRA, C. Abaixo o preconceito. Revista ISTO É, p. 50-51, 1998.

PEREZ, G.H.; NICOLAU, J.C.; ROMANO, B.W.; LARANJEIRA, R. Depressão e Síndromes Isquêmicas Miocárdicas Instáveis: Diferenças entre Homens e Mulheres. Arquivos Brasileiros de Cardiologia. Volume 85, No.5, Novembro, 2005.

RODRÍGUEZ, J.M. Guias Práticos de Enfermagem: EMERGÊnCIAS. Trad. Maria Tereza Ramalhal Teixeira. Rio de Janeiro: McGraw-Hill, 2000. RONDINA, R.C.; GORAYEB, R.; BOTELHO, C. Relação entre tabagismo e transtornos psiquiátricos. Rev. Psiq. Clín. 30(6):221-228, 2003. 
RONDINA, R.C.; GORAYEB, R.; BOTELHO, C. Características psicológicas associadas ao comportamento de fumar tabaco. J Bras Pneumol. 2007; 33(5):592-601.

ROSAS, M. Aspectos psicológicos do sofrimento do doente. Nursing, n.120, ano 10, março de 1998.

SADOCK, B.J. SADOCK, V.A. Compêndio de Psiquiatria. 9a Edição. Porto Alegre: Artmed, 2007.

SELIGMAN, M.P.E. Helplessness: on depression, development, and health. San Francisco: Freeman, 1975.

SILVA, M.C.F.; FUREGATO, A.R.F.; COSTA, M.L.Junior. Depressão: pontos de vista e conhecimento de enfermeiros da rede básica de saúde. Rev Latino-am Enfermagem, 11(1): 7-13, janeiro-fevereiro, 2003.

STEER, R.A.; BECK, A.T.; RISKIND, J.H.; BROWN, G. Relationship between the Beck Depression Inventory and the Hamilton rating scale for depression in depressed outpatients. J Psychopathol Behav Assess, 9:327-39, 1987.

TEIXEIRA, M.B. Assistência de enfermagem a paciente deprimido. Rev Paul. Enf., v.12, n.1, jan/abr., 1993.

TENG, C.T.; HUMES, E.C.; DEMETRIO, F.N. Depressão e comorbidades clínicas. Rev Psiq. Clín. 32(3):149-159,2005.

TENÓRIO, F. A reforma psiquiátrica brasileira da década de 1980 aos dias atuais: história e conceitos, in: Historia, Ciências e Saúde Manguinhos, Rio de Janeiro, Vol.9(1): 25-29, jan-abr. 2002. 
TRAVELBEE, J. Intervención en enfermeria psiquiátrica. Organización Panamericana de la Salud. Organización Mundial de la Salud, Colômbia: Carvajal, 1982.

WEHBE, G.; GALVÃO, C.M. O enfermeiro de unidade de emergência de hospital privado: algumas considerações. Rev Latino-am Enfermagem, 9(2): 86-90, março; 2001.

WILLIAN, A.; FANN, C.S.; STRASSER, P.B. Depression in the workplace: impact on employees. Official Journal of the American Association of Occupational Health Nurses (AAOHN Journal), V. 47, n. 11, November, 1999. 
INSTRUMENTO DE IDENTIFICAÇÃO DOS USUÁRIOS DO PLANTÃO NOTURNO DE UMA UNIDADE DE EMERGÊNCIA.

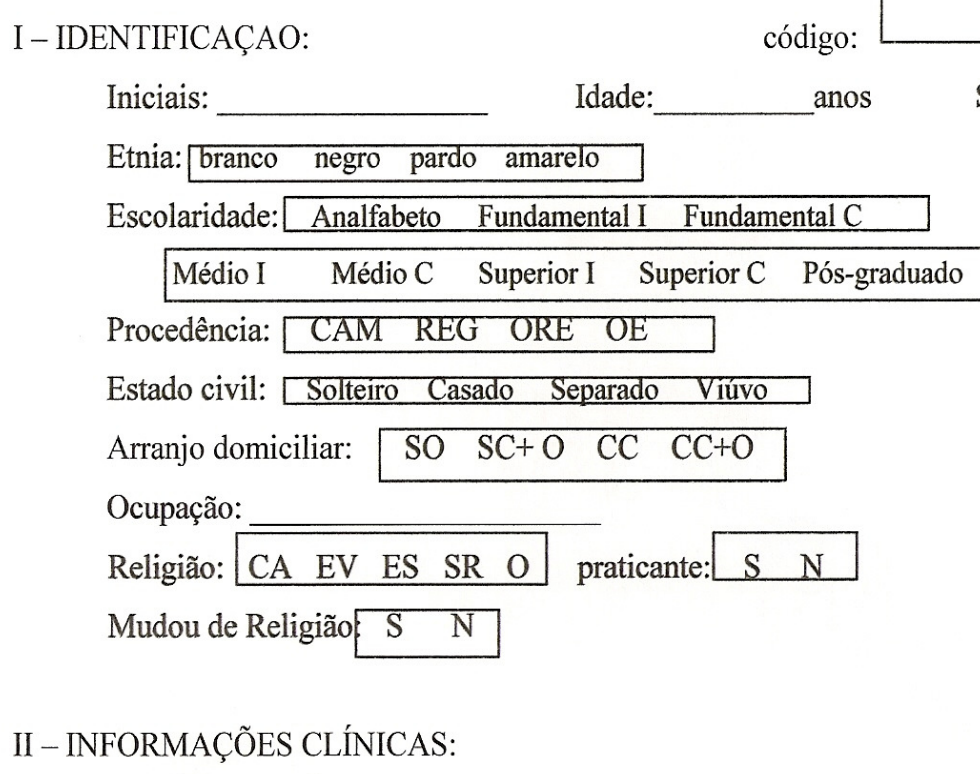

- Queixa com que chegou ao pronto socorro:

- Pressão arterial: $\mathrm{X}$ Pulso: bpm Temperatura: o

- Medicações: (Nome/ Tempo de uso/ Dose/ Via/ Freqüência)

- Número de consultas em 2007:

- Doenças Crônicas: Diabetes: $\mathrm{S}-\mathrm{N}$ Obesidade: $\mathrm{S}-\mathrm{N}$ Hipertensão: $\mathrm{S}-\mathrm{N}$ IAM: $\mathrm{S}-\mathrm{N}$ Outras:

Em tratamento: $\mathrm{S}-\mathrm{N}$ porque:

- Diagnóstico de depressão: $\mathrm{S}-\mathrm{N}$ Tratamento: $\mathrm{S}-\mathrm{N}$

- Sono: Horários: Insônia: $\mathrm{S}-\mathrm{N}$ Freqüência: Inicial Intermediária Final

- Atividade Física: Caminhada Corrida Ginástica Jogos Outros Realizados: Sozinho Acompanhado

- Alimentação: (especificar tipos e horários): 
- Habitos:

Fumo: $\mathrm{S}-\mathrm{N}$ Quantidade: dia sem. Tempo: anos

Álcool: $\mathrm{S}-\mathrm{N}$ Quantidade: dia sem. Tempo: anos

Subst. Ilícitas: S-N Quant. dia sem. Tempo: anos Jogos: $\mathrm{S}-\mathrm{N}$ Tipo: Freqüência:

- Alguma vez procurou serviço de psiquiatria ou psicologia: $\mathrm{S}-\mathrm{N}$ Qual foi a situação:

III - CONTEXTUALIZAÇÃO PSICOSSOCIAL:

a) Evento marcante nos últimos 12 meses:

b) Problemas de relacionamento: pai/mãe filhos cônjuge amigos colegas

Separação/divorcio: $\mathrm{S}-\mathrm{N}$

Outros problemas de relacionamento:

c) Problemas de ordem familiar: Doença Óbito Violência Álcool/drogas

Especificar:

d) Problemas econômicos: $\mathrm{S}-\mathrm{N}$

e) Aposentadoria: $\mathrm{S}-\mathrm{N}$

f) Quão satisfeito você está em sua moradia: nada pouco médio bastante muito

g) Mudança de residência: $\mathrm{S}-\mathrm{N}$

h) Uso de recursos da comunidade: Supermercado Igreja Padaria

\begin{tabular}{|llll|}
\hline Farmácia Posto de Saúde Praça Delegacia Escola & \\
\hline
\end{tabular}

i) Lazer: TV Vídeo/ DVD Música Rádio Cinema

Baile Praça Shopping Centro

Outros: (especificar)

Realizados: Sozinho Acompanhado

j) Ocupações voluntárias: $\mathrm{S}-\mathrm{N}$ 
ANEXO 2

INVENTÁRIO DE BECK

Dia: mês: ano: Iniciais: Idade: Sexo: $\mathrm{M}-\mathrm{F}$

Estado Civil: solteiro/ casado/ amasiado/ viúvo/ separado/ divorciado

Neste questionário há 21 grupos de afirmativas. Por favor, leia cada grupo de afirmações com cuidado. Então escolha a única afirmação em cada grupo que melhor descreve o modo como você esteve se sentindo na SEMANA PASSADA, INCLUSIVE HOJE. Circule o número do lado da afirmação que você escolheu. Leia TODAS as afirmações em cada grupo ANTES de fazer a sua escolha. Não deixe nenhuma questão sem resposta.

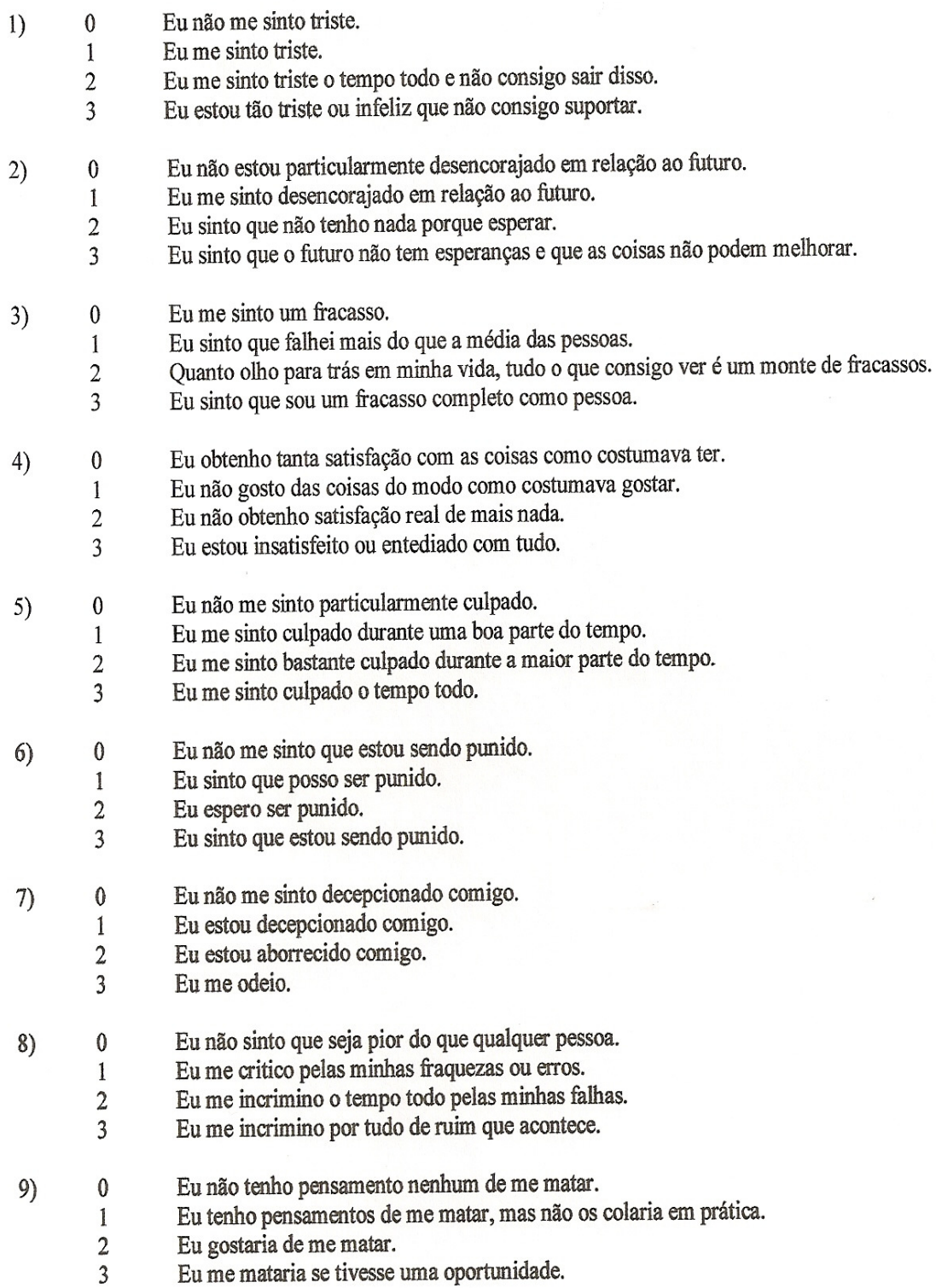

4) 0 Eu obtenho tanta satisfação com as coisas como costumava ter.

1 Eu não gosto das coisas do modo como costumava gostar.

2 Eu não obtenho satisfação real de mais nada.

3 Eu estou insatisfeito ou entediado com tudo.

5) $\quad 0 \quad$ Eu não me sinto particularmente culpado.

1 Eu me sinto culpado durante uma boa parte do tempo.

2 Eu me sinto bastante culpado durante a maior parte do tempo.

3 Eu me sinto culpado o tempo todo.

6) $\quad 0 \quad$ Eu não me sinto que estou sendo punido

Eu sinto que posso ser punido.

Eu espero ser punido.

Eu sinto que estou sendo punido.

7) 0 Eu não me sinto decepcionado comigo.

Eu estou decepcionado comigo.

Eu estou aborrecido comigo.

Eu me odeio.

8) 0 Eu não sinto que seja pior do que qualquer pessoa.

Eu me critico pelas minhas fraquezas ou erros.

Eu me incrimino o tempo todo pelas minhas falhas.

Eu me incrimino por tudo de ruim que acontece.

9) 0 Eu não tenho pensamento nenhum de me matar.

Eu tenho pensamentos de me matar, mas não os colaria em prática.

Eu gostaria de me matar.

Eu me mataria se tivesse uma oportunidade. 
10) 0 Eu não choro mais que o habitual.

Eu choro mais agora do que costumava chorar.

2 Eu choro o tempo inteiro agora.
3 Eu costumava ser capaz de chorar, mas agora eu não consigo chorar mesmo que queira.

11) 0 Eu estou mais irritado agora do que sempre estou.

Eu fico aborrecido ou irritado mais facilmente do que costumava ficar.

Eu me sinto irritado o tempo inteiro agora.

Eu não fico nem um pouco irritado por coisas que costumavam me irritar.

12) 0 Eu não perdi o interesse pelas outras pessoas.

Eu estou menos interessado nas outras pessoas do que costumava estar.

Eu perdia a maior parte do meu interesse pelas outras pessoas.

Eu perdi todo o meu interesse pelas outras pessoas.

13) 0

Eu tomo decisões mais ou menos tão bem quanto eu sempre consegui.

Eu adio tomar decisões mais do que costumava adiar.

Eu tenho maior dificuldade para tomar decisões do que antes.

Eu não consigo mais tomar decisão alguma.

14) 0

Eu não sinto que minha aparência esteja pior do que era.

Eu estou preocupado que esteja parecendo velho ou não atraente.

Eu sinto que há mudanças permanentes na minha aparência que me fazem parecer não atraente.

Eu acredito que pareço feio.

15) 0 Eu consigo trabalhar aproximadamente tão bem quanto antes.

É necessário um esforço extra para começar qualquer coisa.

Eu tenho que me forçar muito para fazer qualquer coisa.

Eu não consigo mais fazer trabalho algum.

16) 0 Eu consigo dormir tão bern quanto o habitual.

Eu não durmo tão bem quanto costumava dormir.

Eu acordo 1 a 2 horas mais cedo do que o habitual e acho dificil voltar a dormir

Eu acordo varias horas mais cedo do que costumava e não consigo voltar a dormir.

17) 0 Eu não fico mais cansado que o habitual.

Eu fico cansado mais facilmente do que costumava ficar.

Eu fico cansado ao fazer quase qualquer coisa.

Eu estou cansado demais para fazer qualquer coisa.

18) 0 Meu apetite não está pior do que o habitual.

1 Meu apetite não está tão bom quanto costumava ser.

2 Meu apetite está muito pior agota.

3 Não tenho mais nenhum apetite.

19) 0 Eu perdi pouco ou nenhum peso ultimamente.

Eu perdi mais de 2,5 Kg.

Eu perdi mais de $5 \mathrm{Kg}$.

Eu perdi mais de $7,5 \mathrm{Kg}$.

Eu estou propositalmente tentando perder peso, comendo menos: $\operatorname{SIM}($ ) NÃO( )

20)

Eu não estou mais preocupado sobre a minha saúde do que o habitual.

Eu estou preoupado com problemas isicoss comomalestrese dares cu desconforto tomacal, ou consipaçẫ.

Eu estou muito preocupado com meus problemas físicos e é dificil pensar em outras coisas.

Eu estou tão preocupado com meus problemas físicos que não consigo pensar em mais nada.

21) 0 Eu não percebi nenhuma mudança recente em meu interesse por sexo.

Eu estou menos interessado em sexo do que costumava estar.

Eu estou muito menos interessado em sexo agora.

3 Eu perdi completamente o interesse por sexo. 


\section{TERMO DE CONSENTIMENTO LIVRE E ESCLARECIDO}

Eu, IGOR PEREIRA DOS SANTOS, enfermeiro, aluno do Mestrado em Enfermagem Psiquiátrica da EERP - USP, sob orientação da Profa. Dra. Antonia Regina Ferreira Furegato, estou desenvolvendo a pesquisa intitulada: "AVALIAÇAO DA PRESENÇA DE DEPRESSÃO ENTRE USUÁRIOS DE PLANTÃO NOTURNO EM UNIDADE DE EMERGENNCIA", que tem como objetivo avaliar a presença de depressão nos usuários do plantão noturno do pronto socorro do Hospital Irmãos Penteado. Utilizamos dois instrumentos, um de caracterização do indivíduo da pesquisa, e outro o "Inventário de Beck", traduzido e validado para o português, sendo amplamente empregado em pesquisas desta natureza.

A sua participação nesta pesquisa não implica em nenhum risco ou prejuízo de qualquer natureza e the é assegurado o sigilo das informações colhidas, bem como sua privacidade e a liberdade de se recusar em participar, ou retirar seu consentimento em qualquer fase da pesquisa sem qualquer penalização. Você não terá nenhum tipo de despesas nem receberá nenhum pagamento. Os dados somente serão usados para fins científicos esperando que seus resultados possam contribuir para a implementação de melhoria na assistência.

$\mathrm{Eu}$, declaro que

li este termo e concordo, voluntariamente, em participar desta pesquisa conforme os termos descritos.

Campinas, de de 20

Ass.: $\mathrm{N}^{0} \mathrm{RG}$ :

\section{IGOR PEREIRA DOS SANTOS}

RG: 20269142-1 COREn: 0112775.SP

Rua Luzitana, 1420, apto 13, Centro, Campinas. SP

Fone: (19) 92348083 - 37377000 (trab.)

(PESQUISADOR) 

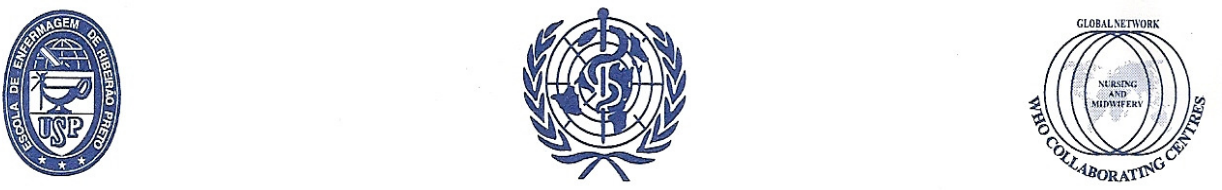

ESCOLA DE ENFERMAGEM DE RIBEIRÃO PRETO - UNIVERSIDADE DE SÃO PAULO CENTRO COLABORADOR DA ORGANIZAÇÃO MUNDIAL DA SAÚDE PARA O DESENVOLVIMENTO DA PESQUISA EM ENFERMAGEM

Avenida Bandeirantes, 3900 - Campus Universitário - Ribeirão Preto - CEP 14040-902 - São Paulo - Brasil FAX: (55) - 16-3633-3271 / 3602-4419 / TELEFONE: (55) - 16 - 3602-3382

\section{COMITÊ DE ÉTICA EM PESQUISA DA EERP/USP}

Of.CEP-EERP/USP - 187/2007

Ribeirão Preto, 16 de agosto de 2007

Prezada Senhora,

Comunicamos que o projeto de pesquisa, abaixo especificado, foi analisado e considerado APROVADO, pelo Comitê de Ética em Pesquisa da Escola de Enfermagem de Ribeirão Preto da Universidade de São Paulo, em sua $98^{a}$ Reunião Ordinária, realizada em 15 de agosto de 2007.

Protocolo: $n^{0} 0814 / 2007$

Projeto: AVALIAÇÃO DA PRESENÇA DE DEPRESSÃO ENTRE USUÁRIOS DE PLANTÃO NOTURNO EM UNNIDADE DE EMERGÊNCIA.

Pesquisadores: Antonia Regina Ferreira Furegato Igor Pereira dos Santos

Em atendimento à Resolução 196/96, deverá ser encaminhado ao CEP o relatório final da pesquisa e a publicação de seus resultados, para acompanhamento, bem como comunicada qualquer intercorrência ou a sua interrupção.

Atenciosamente,

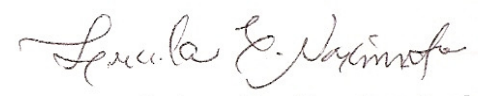

Profa ${ }^{a}$ Dra ${ }^{\mathrm{a}}$. Lucila Castanheira Nascimento

Coordenadora do CEP-EERP/USP

Ilma. Sra.

Prof $^{\mathrm{a}} \mathrm{Dr}^{\mathrm{a}}$ Antonia Regina Ferreira Furegato

Dept $^{\circ}$ de Enfermagem Psiquiátrica e Ciências Humanas

Escola de Enfermagem de Ribeirão Preto - USP 
ANEXO 5

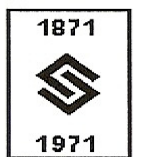

\author{
Irmandade de Misericórdia de Campinas \\ Hospital Irmãos Penteado e Santa Casa de Misericórdia \\ CNPJ 46.045.290/0001-90
}

COMITÊ DE ÉTICA EM PESQUISA

Irmandade de Misericórdia de Campinas

Hospital Irmãos Penteado

Campinas, 27 de Setembro de 2007.

\author{
PARECER PROJETO: MESTRADO \\ REGISTRO NO CEP: 026/07 \\ FR: 141052
}

\title{
I - IDENTIFICAÇÃO:
}

PROJETO: "Avaliação da presença de depressão entre usuários de plantão noturno em unidade de emergência".

$>$ PESQUISADOR RESPONSÁVEL: Igor Pereira dos Santos(mestrando).

$>$ INSTITUIÇÃO: Irmandade de Misericórdia de Campinas Hospital Irmãos Penteado e Santa Casa de Misericórdia.

$>$ APRESENTAÇÃO AO CEP: 26/09/07.

\section{II - OBJETIVOS:}

Conhecer a presença de depressão em usuários do plantão noturno em uma unidade de emergência em instituição privada e relacionar este fato aos condicionantes clínicos e contextuais.

\section{III - COMENTÁRIOS DOS RELATORES:}

O protocolo foi bem elaborado com bibliografia pertinente. Com relação aos Aspectos Éticos, a proposta segue as normas da Resolução 196/96. O Termo de Consentimento Livre e Esclarecido (TCLE) apresenta linguagem acessível à compreensão dos sujeitos da pesquisa contendo as informações necessárias: justificativa, objetivos e procedimentos da pesquisa, desconfortos, riscos e benefícios esperados, liberdade do sujeito em se recusar a participar ou retirar seu consentimento a qualquer momento sem penalização, garantia de sigilo, formas de ressarcimento e indenização.

Este protocolo fora considerado APROVADO pelo CEP Escola de Enfermagem de Ribeirão Preto da Universidade de São Paulo em 15 de Agosto de 2007.

\section{IV - PARECER DO CEP:}

O Comitê de Ética em Pesquisa da Irmandade de Misericórdia de Campinas-Hospital Irmãos Penteado após acatar os pareceres dos membros-relatores previamente designados para o presente caso, resolve APROVAR o Protocolo de Pesquisa supracitado: 


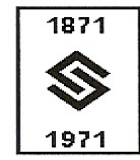

Irmandade de Misericórdia de Campinas

Hospital Irmãos Penteado e Santa Casa de Misericórdia

CNPJ 46.045.290/0001-90

COMITÊ DE ÉTICA EM PESQUISA

Irmandade de Misericórdia de Campinas

Hospital Irmãos Penteado

V- DATA DA REUNIÃO:

APROVADO pelo CEP Irmandade de Misericórdia de Campinas - Hospital Irmãos Penteado em 26 de Setembro do 2007.

Em atendimento à Resolução 196/96, deverá ser encaminhado ao CEP o relatório final da pesquisa e a publicação de seus resultados, para acompanhamento, bem como comunicada qualquer intercorrência ou a sua interrupção.

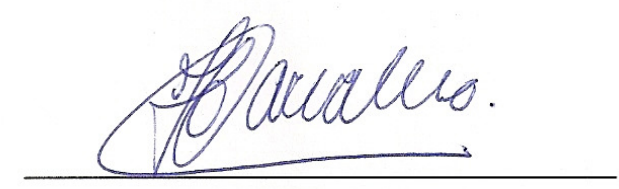

Dr. João Ernesto de Carvalho

Coordenador do Comitê de Ética em Pesquisa Irmandade de Misericórdia de Campinas Hospital Irmãos Penteado 


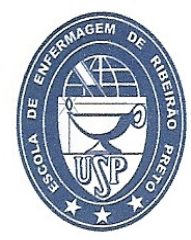

\section{ESCOLA DE ENFERMAGEM DE RIBEIRÃO PRETO \\ UNIVERSIDADE DE SÃO PAULO}

Campinas, 02 de outubro de 2007

IImo. Sr. Dr. Carlos Eduardo Lima

Illma. Sr. Enfa. Tatiana Moreno

Respectivos coordenadores médico e de enfermagem

Pronto Socorro Hospital Irmãos Penteado.

Venho, por este intermédio, solicitar de Vossas Senhorias autorização para a realização da coleta de dados do projeto de pesquisa - nível mestrado - intitulado: "Avaliacão da presença de depressão entre usuários de plantão noturno em unidade de emergência". Com vistas ao desenvolvimento de minha Dissertação vinculada ao Programa de Pós Graduação em Enfermagem Psiquiátrica da EERP/USP.

O referido projeto foi aprovado pelo Comitê de Ética da instituição universitária vinculada, como também tem autorização do Comitê de Ética em pesquisa do Hospital Irmãos Penteado e da administração, conforme anexos.

A coleta de dados será efetuada com instrumentos apropriados, testados e validados nacional e internacionalmente no tocante a presença de sintomatologia indicativa de depressão, sendo que o projeto é importante não somente como fonte de dados para o pesquisador, como ferramenta para uma possível melhoria na qualidade do serviço prestado, bem como contribuição ao papel educacional e de pesquisa que o Hospital vem desempenhando.

Agradeço antecipadamente a atenção.

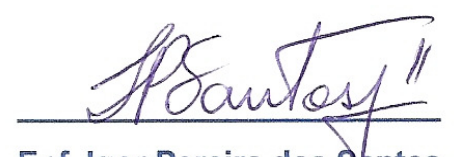

Enf. Igor Pereira dos Santos Mestrando - No. USP 2375444

Coren: 0112775
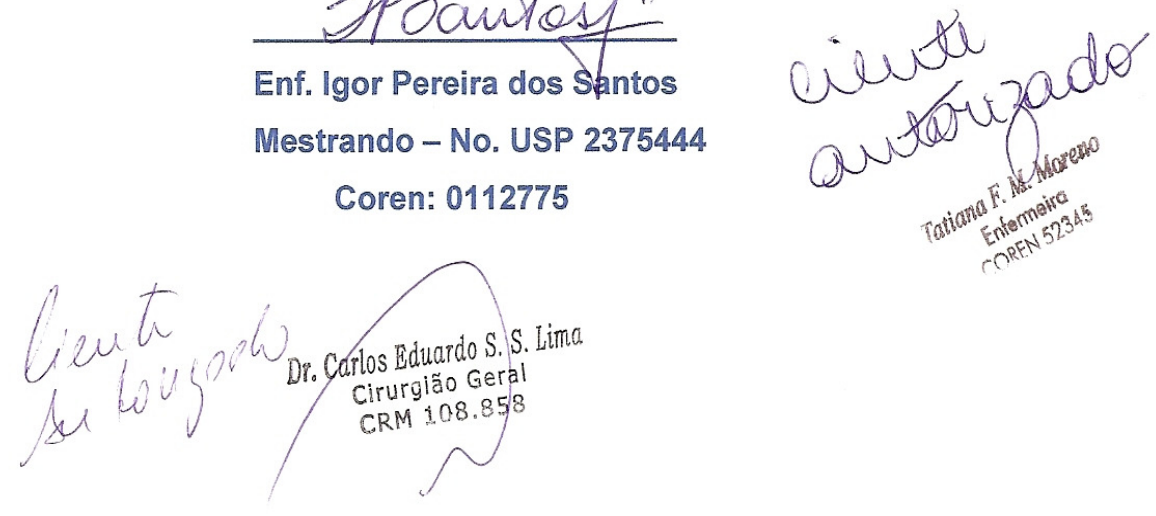